\title{
The Historic Centre of Urbino, UNESCO World Heritage (Marche Region, Italy): an Urban-Geological Itinerary Across the Building and Ornamental Stones
}

\author{
Patrizia Santi $^{1}$ - Mario Tramontana ${ }^{1} \cdot$ Gianluigi Tonelli $^{1} \cdot$ Alberto Renzulli $^{1} \cdot$ Francesco Veneri $^{1}$
}

Received: 26 March 2021 / Accepted: 23 August 2021 / Published online: 12 September 2021

(c) The Author(s) 2021, corrected publication 2022

\begin{abstract}
The local and extra-regional (national and transnational) stones mainly used as building and ornamental materials in the historic centre of Urbino (UNESCO World Heritage List) were unravelled through a detailed geological and petrographic study. The types of building stones used in the past for the development of an urban centre were mostly affected by the availability of suitable geomaterials in the surrounding areas. For this reason, the stones found in the historical buildings of Urbino generally come from the local sedimentary formations (mostly limestones) belonging to the Umbria-Marche-Romagna Succession Auct., which crops out in the Northern Marche Apennines. Only some ornamental highly prized stones used for monuments and decorations come from both extra-regional Italian areas (Alps, other sectors of the Northern Apennines) and foreign countries (France, Egypt). A brief description of the Northern Marche geology was also reported to exactly match the local provenance of the stones, so highlighting the relationship between the territory and the architecture of Urbino. Because of obvious conservation reasons, no samples were collected from buildings or monuments and only autoptic observations, together with a detailed historical and bibliographic research, were carried out to identify the different materials and the provenance areas. Besides the availability of the local sedimentary rocks, we emphasised how the choice of the building and ornamental stones could have been also influenced by the historic period and artistic style, aesthetic features, economic and social importance of the building and/or monument and the relationship to some distinguished personality (e.g., Pope Clemente XI). An open-air stone itinerary across significant places (10 stops and additional sites and monuments in the urban area) is finally proposed for the best fruition of the geological and cultural heritage of Urbino, also aimed at geotourism development.
\end{abstract}

Keywords Building and ornamental stones · Quarries · Urban geology · Geotourism · UNESCO World Heritage List · Urbino

\section{Introduction}

According to the UNESCO Convention concerning the Protection of the World Cultural and Natural Heritage (UNESCO 1972), it is not possible to separate natural heritage from building heritage. The study of building and ornamental stones used through the historical periods thus represents one of the main approaches useful to combine geology and

Francesco Veneri

francesco.veneri@uniurb.it

1 Dipartimento di Scienze Pure e Applicate, Università degli Studi di Urbino Carlo Bo, Campus Scientifico "Enrico Mattei”, Urbino, Italia cultural heritage within an urban environment. It is worth to note that in the historic cities natural stones were used as building and/or ornamental material. The term building stone is generally referred to stones used for masonry in the construction of foundations, walls, columns and arches, whereas ornamental stones, due to their colours, structure and because they can be easily polished, are strongly suitable for monuments, decorative elements and facings of buildings. However, many uses of stones in building heritage require a compromise between structural and decorative qualities. Building and ornamental stones are recognised as heritage main elements from the cultural, historical, archaeological, architectural and aesthetical point of view, and therefore contain important features resulting from the peculiar meaning of Geological Sciences, and for research 
and cultural education (Brocx and Semeniuk 2019). Traditional building and ornamental stones are part of the visible heritage of cities, whereas their colour, structure, associated history and conservation represent part of the intangible heritage. For a single city, it is possible to recognise and to map the used stones, which allow identifying and differentiating urban traits as valuable assets (Siegesmund and Török 2011; Cooper et al. 2013).

For a better fruition of the geological and cultural heritage, stone itineraries across the urban centres of some Italian cities, such as Bologna (Del Monte 2005), Catania (Punturo et al. 2006), Roma (Giampaolo et al. 2008), Firenze (Pecchioni et al. 2012), Reggio Emilia (Vernia 2014), Torino (Borghi et al. 2014; Gambino et al. 2019), Pisa (Lezzerini et al. 2019) and Petralia Sottana-Palermo (Torre et al. 2020), have been proposed in the last two decades, aimed at developing geotourism. Some "geological walks", promoted by the Societé Geologique de France and the Muséum d'Histoire Naturelle over historical and modern cities of France (De Wever et al. 2017), and other important recent case studies of geotourism reported by Brocx and Semeniuk (2019) and Fio Firi and Maričić (2020) are among the best examples in the world.

The knowledge of the minero-petrographic features and physical-mechanical properties of the used geomaterials in historic cities allows to assess both areas of provenence and potential deterioration patterns, having implications for the planning of conservation strategies for monuments and the definition of restoration priorities. In fact, there are many examples of inappropriate substitutions with natural stones not matching the original ones. This is partly due to the lack of knowledge about the importance of using the same or very similar geomaterials with respect to the original ones to avoid physical or aesthetic damages (Pereira and Marker 2016).

Following the principle that geoheritage and promotion of geological values include buildings, monuments and other man-made features constructed of geological materials (De Wever et al. 2017), the present paper is addressed not only to geologists and petrologists, but also to a wider range of users, including tourists and tour operators. In addition, the interest for building and ornamental stones used in historical urban contexts should contribute to the dissemination of knowledge about the Earth Sciences and also to raise awareness of the geological processes that formed the materials in the first place, that is their intrinsic geological story. Geotourism attempts to transfer geo-knowledge from professional to public levels and the use of this knowledge to feed innovation and product development plays a fundamental role for competitiveness of both tourist destinations and enterprises (Farsani et al. 2014).

\section{Historical and Architectural Background of the City of Urbino}

The historic centre of Urbino (Fig. 1, Marche Region, Central Italy) is described as "a pinnacle of Renaissance art and architecture, harmoniously adapted to its physical site and to its medieval precursor in an exceptional manner" in the UNESCO World Heritage List (1998). The first important architectural remains of Urbino date back to the Roman period (Urvinum Mataurense, third to
Fig. 1 Panoramic view (from South) of the Urbino historic centre

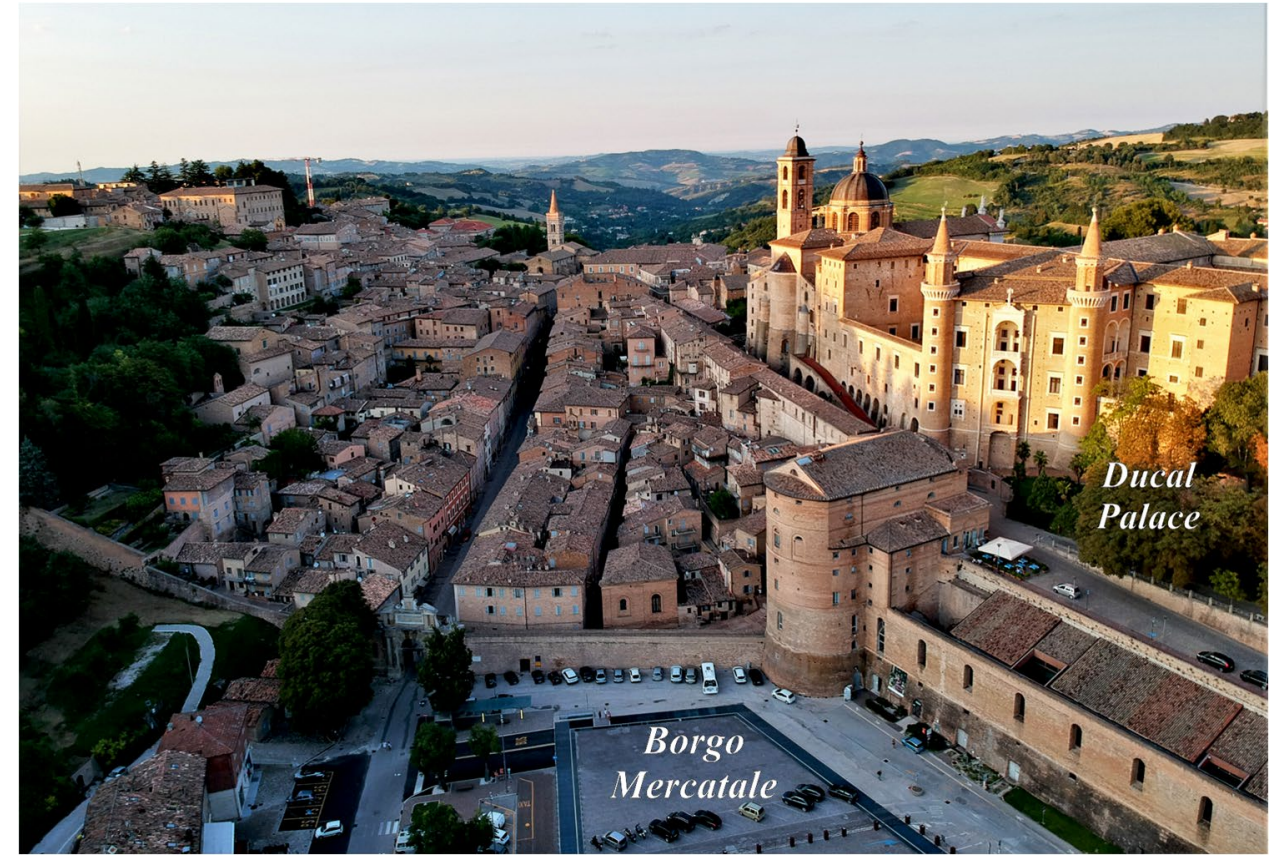


second century BC; Agnati 1999), when the oldest settlements developed upon Il Poggio (Fig. 2), which represents the Southernmost hill of the two ones where the historic centre of the city is currently located. Starting from the Middle Age (eleventh century), the urban settlement extended toward the North, resulting also in the construction of a new system of defensive walls (Luni 1985). Nevertheless, Urbino reached the maximum prosperity in Renaissance. In fact, a massive rebuilding of the city with bricks and local sedimentary stones began in the second half of fifteenth century, under the rule of Federico III da Montefeltro, Duke of Urbino. The new Ducal Palace, attributed to the architects Luciano Laurana and Francesco di Giorgio Martini, was built including the existing Middle Age structures, so becoming the new focus of the urban fabric (Fig. 1). The architectural style of the Palace turns out to be a model for several new constructions of the Italian Renaissance (Mazzini 1982, and references therein). In the 1631, with the annexation of the Ducky of Urbino to the Papal State, the city started to decline up to the eighteenth century, when the Cardinal Giovanni Francesco Albani from Urbino was elected Pope Clemente XI. In this period, the city became once again a flourishing centre and numerous palaces, churches and new monuments were restored or built. A lot of coloured ornamental stones and precious marbles
Fig. 2 The historic centre of Urbino with the location of the main used lithotypes of local (sedimentary rocks) and extra-regional (national and transnational) building and ornamental stones described in the present paper. Circled numbers indicate the ten stops of the open-air itinerary while circled letters mark other buildings and sites mentioned in the text. a via Saffi; b Corso Garibaldi; c Oratorio della Morte; $\mathbf{d}$ Largo San Crescentino; e Corso Matteotti; f Palazzo Ubaldini-Ivarra; $\mathbf{g}$ Santa Maria della Misericordia (old Hospital); h Oratorio di San Giuseppe; i Palazzo Peroli; I Palazzo Battiferri. Roman and Medieval Walls are modified after Luni and Ermeti (2001)

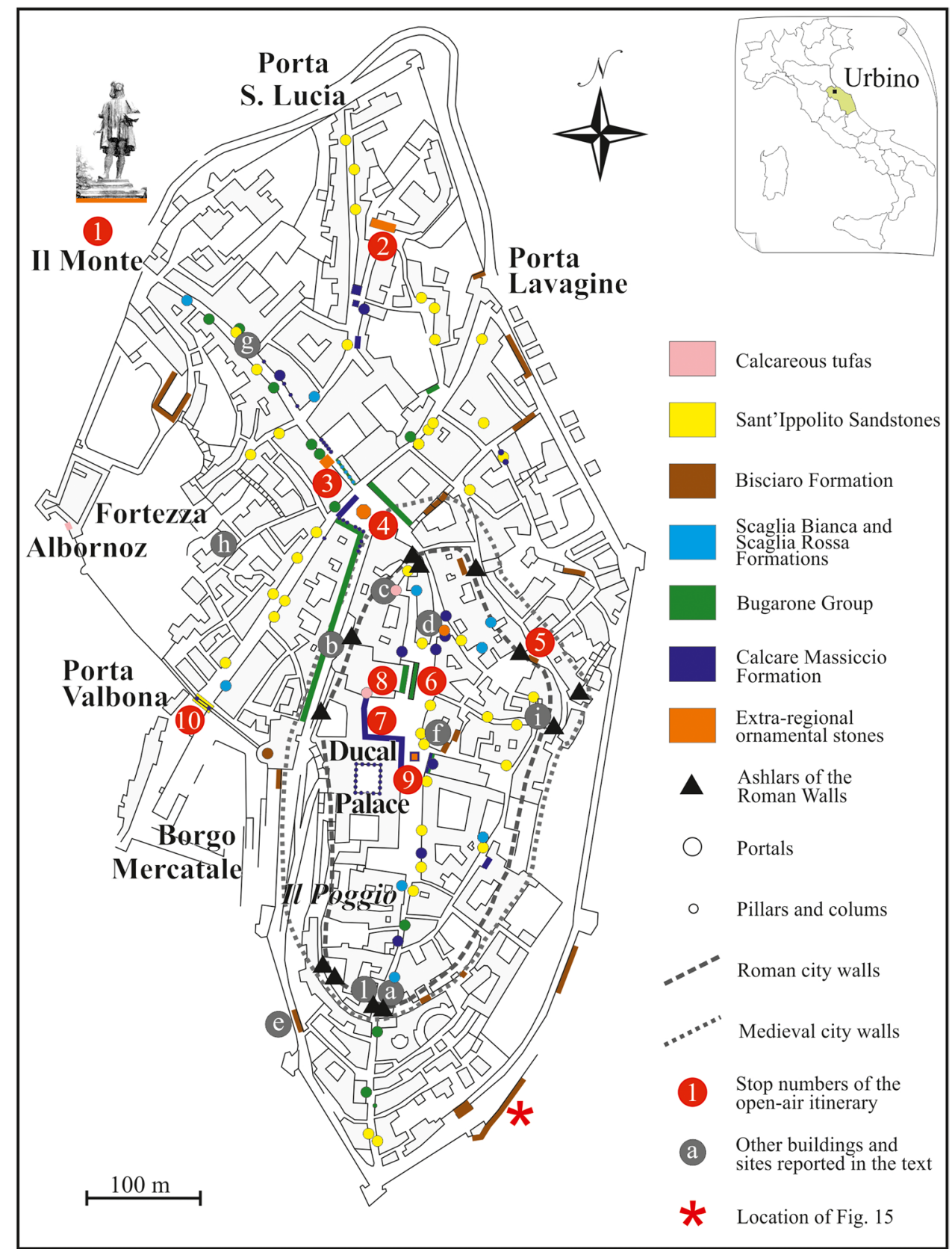


(e.g., columns, slabs, one sarcophagus) and one obelisk coming from spolia of ancient Roman temples were transported to Urbino to be used for monument structures and decorations. Since eighteenth century, the city maintained the areal distribution and the urban fabric as it appears nowadays.

This paper describes and characterises the most used stones in the urban area of Urbino in the framework of the overall architecture of the town. After the historical books of Francesco di Giorgio Martini (1477) and Bernardino Baldi (1587), Rodolico (1953) was the first author reporting a comprehensive description of the most used local building stones characterising the historic centre of Urbino. After this pioneer work, of the middle of the twentieth century, only few papers on the stones of Urbino were published, often focused to a single lithotype or one monument/archaeological context (Micheli 1983; Amadori 1985; Busdraghi and Veneri 1994, 2003; Busdraghi et al. 1994; Busdraghi and Wezel 2002; Amadori et al. 2005; Fiora 2013; Santi et al. 2019; Taelman et al. 2019). In order to fill this gap, different architectural structures (walls, palaces, churches, monuments), dating back from the Roman time to the twelfth century, were described in the present paper considering both building and ornamental stones, including macroscopic features, structure, petrographic description, physical-mechanical properties and, when possible, matching their provenance area. Finally, an open-air building and ornamental stone heritage itinerary was proposed, consisting of 10 stops located in the historic centre of Urbino. Besides these stops, other information about the use of the local stones in additional buildings, pavements and sites throughout the historic centre of the city are also given.

\section{Geomaterials and Methods}

The historic centre of Urbino was mainly built using bricks, and subordinately local stones coming from the adjacent Apennine Chain, where numerous quarries were exploited in ancient times. Sedimentary lithotypes of the Umbria-Marche-Romagna Succession (hereafter UMRS; Conti et al. 2020 and references therein) were commonly employed as building stones in several architectonic structures (e.g., walls and portals). The coupling of pale coloured carbonate stones (i.e., white to pink) with the orange-brown bricks, and, more rarely, with beige sandstones, resulted into an impressive background, where the occasional differently coloured extra-regional ornamental stones (igneous, sedimentary and metamorphic rocks) used for some monuments stand out, being clearly visible. Due to the impossibility to collect samples from the historic centre, this work was mainly developed by autoptic comparative observations with both natural raw materials and collections of ornamental stones, and stone atlases (Borghini 1998; Blanco 1999).

Physical-mechanical features of the local sedimentary lithotypes are reported in Table 1. Although some of them come from the literature, they were compared for the first time in the framework of the geoheritage of Urbino. The apparent uniaxial compressive strength using the Schmidt hammer, directly performed on the geomaterials used for the construction, were elaborated according to Irfan and Dearman (1978).

Samples from quarrying sites of six local sedimentary formations used as building stones were also analysed in thin section using the optical polarising microscopy (OPM; Nikon Opthipot2-Pol instrument) in order to define texture, petrography and fossil components of the geological formations. All the exploited quarries were located relatively close
Table 1 Main physical-mechanical features of the local sedimentary lithologies $\left(\gamma_{d}\right.$ : dry unit weight; $\gamma_{s}$ : specific gravity; $n$ : porosity; Qu: uniaxial compressive strength) from (1) Romeo et al. 2013, (2) Magi 2012, (3) Fausti 2009, (4) Tonelli et al. 2019, (5) Santi et al. 2019,

\begin{tabular}{|c|c|c|c|c|c|}
\hline Formation/Lithology and Geological Age & $\begin{array}{l}\gamma_{d} \\
\left(\mathrm{Mg} / \mathrm{m}^{3}\right)\end{array}$ & $\begin{array}{l}\gamma_{s} \\
\left(\mathrm{Mg} / \mathrm{m}^{3}\right)\end{array}$ & $\begin{array}{l}n \\
(\%)\end{array}$ & $\begin{array}{l}\mathrm{Qu} \\
(\mathrm{MPa})\end{array}$ & $\begin{array}{l}\text { Qua }(\mathrm{MPa}) \\
\text { (present paper) }\end{array}$ \\
\hline $\begin{array}{l}\text { Calcare Massiccio "Travertino Maschio" }(1,2) \\
\text { 200-190 Ma }\end{array}$ & $2.50-2.60$ & $2.68-2.70$ & $3.0-8.0$ & $50-60$ & $41-55$ \\
\hline $\begin{array}{l}\text { Calcare Massiccio "Travertino Femmina" }(1,2) \\
\text { 200-190 Ma }\end{array}$ & $2.11-2.26$ & $2.68-2.70$ & $20-28$ & $30-35$ & - \\
\hline Bugarone Group ${ }^{(3)} 180-150 \mathrm{Ma}$ & $2.65-2.68$ & $2.68-2.72$ & $1.1-2.5$ & $80-120$ & $55-60$ \\
\hline Scaglia Bianca $^{(1)} 100-90 \mathrm{Ma}$ & $2.60-2.68$ & $2.70-2.72$ & $0.5-1.5$ & $100-150$ & $44-64$ \\
\hline Scaglia Rossa ${ }^{(1,4)} 90-40 \mathrm{Ma}$ & $2.58-2.61$ & 2.70 & $1.5-4.5$ & $100-140$ & $40-61$ \\
\hline Bisciaro $^{(1)} 23-17 \mathrm{Ma}$ & $2.42-2.68$ & $2.66-2.71$ & $1-11$ & $60-110$ & $40-65$ \\
\hline Sant'Ippolito Sandstone ${ }^{(5)} 6-5 \mathrm{Ma}$ & $1.63-2.61$ & $2.60-2.73$ & $4-38$ & $12-27$ & $40-45$ \\
\hline Calcareous tufas ${ }^{(6)} 0.01 \mathrm{Ma}-$ present & $1.14-1.68$ & 2.69 & $37-57$ & $2-8^{(7)}$ & $30-45$ \\
\hline
\end{tabular}

(6) Busdraghi and Veneri 2003. (7) New test performed on samples coming from the calcareous tufas quarry (see Fig. 8); Qua: apparent uniaxial compressive strength (Schmidt hammer) 
(not more than $30 \mathrm{~km}$ ) to Urbino (Amadori and Raffaelli 2006; AA.VV. 2007).

\section{An Open-Air Itinerary Across the Building and Ornamental Stones of the Historic Centre of Urbino}

The aim of the itinerary proposed (10 stops; Fig. 2) is to accompany people to discover the different geomaterials used for some historical monuments and palaces, which are representative of the urban architectonic framework of Urbino. It is worth to note that our interest was addressed not only to famous buildings but also to minor monuments and other sites of the cultural heritage, which in some cases are additionally indicated with circled letters in Fig. 2. The itinerary (Fig. 2) runs for about $1.5 \mathrm{~km}$ along the streets of the centre of the city, with an estimated travel time of about $2 \mathrm{~h}$ and characterised by about $120 \mathrm{~m}$ of difference in height (90 $\mathrm{m}$ of descent and $30 \mathrm{~m}$ of ascent), at an altitude ranging between about 470 and $410 \mathrm{~m}$ a.s.l. The proposed sequence of stops (from 1 to 10 ) is functional to travel throughout the city avoiding go back and forth. However, everyone could move according to its curiosity and interest.

\section{Suggested Stops for the Urban-Geological Walk}

\section{Stop 1: The Monument to Raffaello Sanzio}

The idea to dedicate a monument to the famous painter from Urbino dates back to the seventeenth century. However, it was built only at the end of the nineteenth century, due to economic reasons. After the foundation of the Accademia
Raffaello (1869) and the purchase of Raffaello's birthplace (1871-1872), thanks to a fundraising, the city of Urbino convened a public contest to achieve the monument (Sisti 2019). The sculptor Luigi Belli from Turin made the monument, which was inaugurated in 1897 . Initially located in the Duca Federico Square (see stop 7), from 1947 the monument was finally placed in the park close to Piazzale Roma (this stop).

Some metamorphic and igneous intrusive rocks coming from the Alps and the Tuscany Region (Apuan Carrara district) are recognisable in the pedestal of the bronze statue of Raffaello (3.84 m high). White marble with decorative blocks/plinths of brownish-violet syenite, green slabs of ophicalcite and pink limestone slabs and medallions (Fig. 3a) mainly constitute the polychrome basement of the monument. All around the monument, other bronze statues and six putti made of white marble can be observed. A magnificent pink granite staircase borders the lower base.

The crystalline marble, which is the most used geomaterial, is constituted by a pure, very fine-grained white calcite (macroscopically estimated maximum grain size MGS $<<1 \mathrm{~mm}$, Fig. 3b1), characterised by an isotropic texture with homeoblastic (saccaroid) structure, without veins or accessory coloured minerals. All these features are typical of the highly prized metamorphic stone (marble) coming from the Carrara District (Apuan Alps, Tuscany Region; Carmignani et al. 2007). In particular, we believe that it could be the Bianco Ordinario variety, used for the bas-reliefs decorating the die and the six putti. The remarkable plinths in the lower and upper portions of the die are constituted by a brownish-violet syenite, whose petrographic autoptic features correspond to the so-called Balma Syenite (Fig. 3b2). It consists of a medium grain-sized intrusive
Fig. 3 Stop 1: the monument to Raffaello Sanzio (a) and a detail (b) where some extra-regional lithotypes can be seen: 1, white Carrara marble; 2, Balma Syenite; 3, Verde Avèr ophicalcite; 4, Rosso di Francia limestone
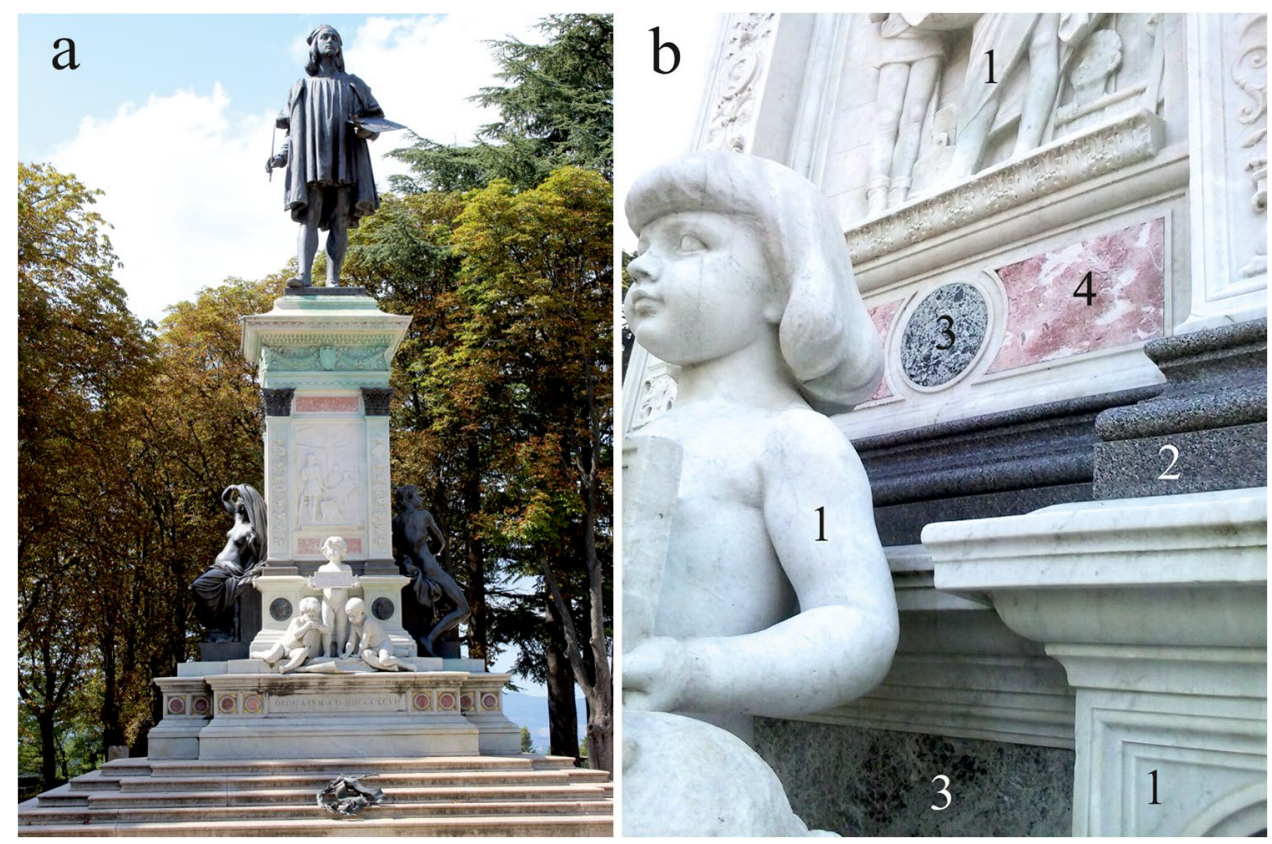
rock, macroscopically characterised by brown-violet K-feldspar, less abundant plagioclase and amphibole and biotite among mafic minerals; quartz is rarely detectable. This very hard Alpine stone coming from the Oligocene intrusive bodies of the Sesia Lanzo Zone, crops out along the Cerro Valley (Western Alps, Piedmont Region; Borghi et al. 2014). The green small decorative slabs of the second base of the monument (Fig. 3b3) can be referable to one of the Western alpine green ophicalcites (Borghi et al. 2014) formed through a low to medium grade metamorphism of Jurassic-Cretaceous ultrabasic rocks (mantle peridotites). In particular, the employed stone, showing a heterogeneous structure and colour, consisting of green clasts randomly dispersed within a whitish-greenish calcite matrix, can be ascribed to the Verde Avèr commercial variety. The decorative small slabs and medallions are constituted by pink limestones whose colour is due to the presence of hematite in the carbonate matrix. Although the autoptic observation does not allow an unambiguous classification, the small slabs could be referred to the Rouge Languedoc (Bourrouilh and Bourque 1995a, b) also known as Rosso di Francia (Pullen 2016). This stone is a fractured haematitic metamorphosed Devonian limestone with white randomly dispersed, shapeless and elongated calcite elements (stromatactis) and veins (Fig. 3b4) coming from the South of France (Bourrouilh and Bourque 1995a, b; Bradley 2000). Instead, the very damaged medallions consist of a marly limestone with little calcite veins making the stone inhomogeneous and then subjected to flaking and differential erosion. This material most probably belongs to the so-called Marmo Rosso coming from the Scaglia Toscana Formation (Upper Cretaceous-Eocene; Pecchioni et al. 2012). Concerning the stairs leading to the monument, a famous and widespread Alpine pink fine- to medium-grained granite (i.e., the Baveno granite) was used. $\mathrm{K}$-feldspar (orthoclase), which is typically pink in colour due to the haematitic inclusions, quartz and biotite crystals were also macroscopically recognised. The name of this Palaeozoic intrusive rock derives from the main quarries located near the city of Baveno, on the Lago Maggiore (Western Alps, Piedmont Region; Fiora et al. 2002; Borghi et al. 2014).

\section{Stop 2: Giovanni Pascoli School}

This palace represents the unique example, in the city, of the early twentieth century Italian rationalism (Fig. 4a). The architect Amos Luchetti Gentiloni, who already worked in Urbino, was appointed to project the new school edifice. The structure, built in the centre of the city on the historical gardens of the Albani Palace, was opened in 1934 with the name "Scuola XXVIII Ottobre" in honour of the Italian Fascism. Only in 1955, in the centenary of the birth of the famous poet Giovanni Pascoli, who stayed in Urbino for its

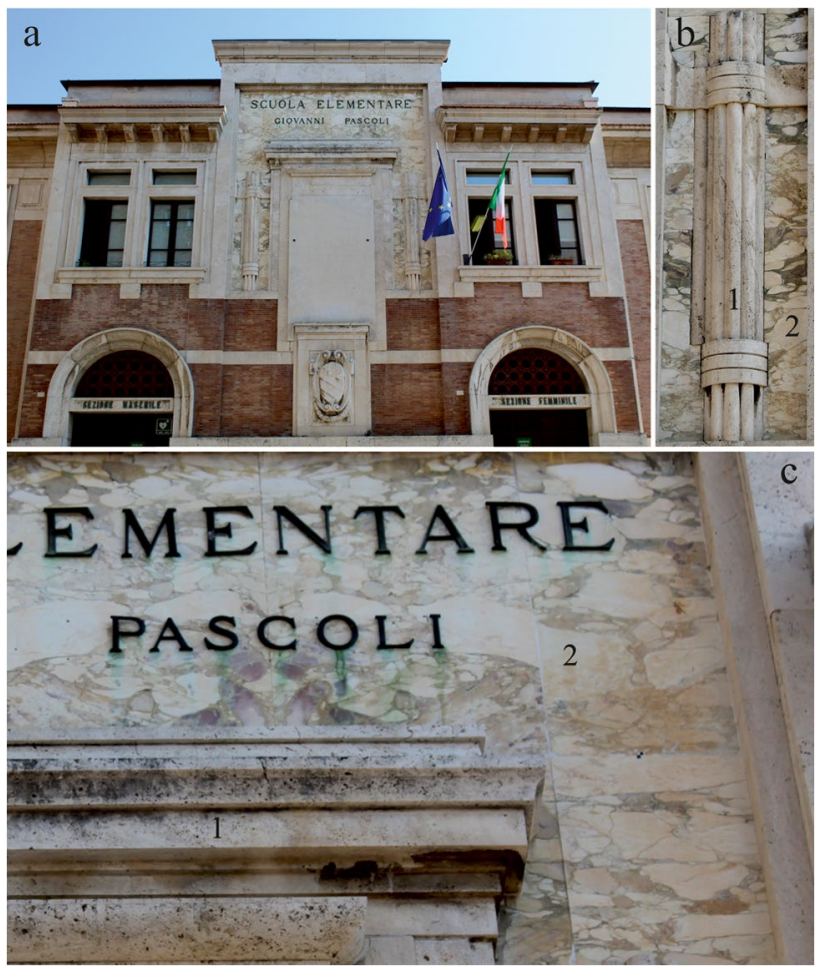

Fig. 4 Stop 2: the façade of the Pascoli School (a) with particulars of the Travertine slabs (b1 and $\mathbf{c} 1)$ and of the brecciated marble from Carrara District (b2 and $\mathbf{c} 2$ )

studies, the school was dedicated to him (AA.VV. 2016a). In accordance with the Rationalist style, it is worth to note the use of bricks and Italian ornamental stones. In the façade we can recognise a wide use of slabs of whitish stromatolitic travertine stricto sensu (Fig. 4b1 and Fig. 4c1) characterised by typical massive to porous structure with concretions and laminar bands giving to the portals, windows, cornices and other architectural elements such as "fasci littori" (symbols of the Italian Fascism, Fig. 4b1) a decorative aspect. The provenance of this stone is probably from the Ascoli Piceno District (in the Southern Marche Region) where an important source area of travertine, tens of metres thick (Della Porta et al. 2017) was exploited since the Roman time. The central part of the façade is covered with slabs of whitishyellowish brecciated marble (Fig. 4b2 and Fig. 4c2), most probably coming from the Carrara District (Apuan Alps, Tuscany Region; Carmignani et al. 2007).

\section{Stop 3: The Façade of the Caffetteria Tabaccheria Boni}

This original emporium, which was opened in 1920, represents the unique Art Nouveau façade of the centre of Urbino (Fig. 5a). Highly prized ornamental stones were chosen to decorate the façade, such as a white marble (Fig. 5a1), a yellow carbonate stone for the pilasters 
Fig. 5 Stop 3: the Art Nouveau façade of the Caffetteria Tabaccheria Boni (a) with 1, white Carrara marble; 2, Giallo di Verona limestone; and 3, Rosso Levanto ophicalcite; details of Giallo di Verona (b) and Rosso Levanto (c)
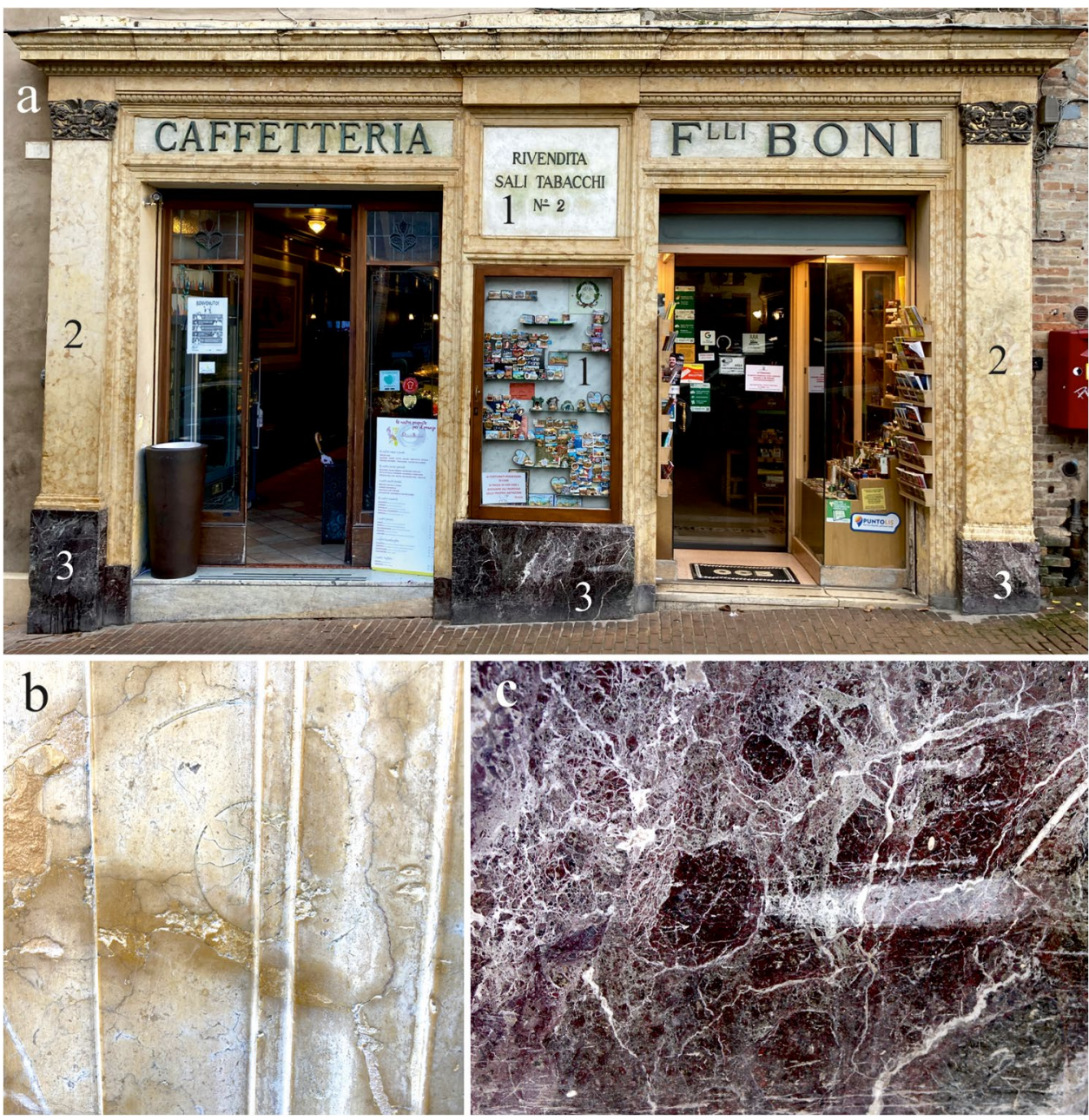

(Fig. 5a2) and a reddish veined stone (Fig. 5a3) for the socle. In particular, the pure white crystalline marble, used as large slabs with superimposed bronze letters shows the typical macroscopic features of the white Carrara marble, in particular the Bianco Ordinario variety (Apuan Alps, Tuscany Region; Carmignani et al. 2007). The main structure of the façade is made of a yellow nodular finegrained (biomicrite) limestone, containing frequent macrofossils such as Ammonites (Fig. 5a2 and Fig. 5b). This stone shows a little variable colour, due to the presence of pale yellow centimetric nodules and irregular white calcite veins. All macroscopic features correspond to those of the Giallo di Verona sedimentary lithotype (Jurassic in age) coming from the Veneto Region stone District (Valpolicella; Blanco 1999) in Northern Italy. Finally, the socle was built using slabs of the Rosso Levanto ophicalcite, a highly prized stone characterised by dark-red to dark-green clasts randomly dispersed in a carbonate matrix and by a network of white calcite veins (Fig. $5 \mathrm{a} 3$ and Fig. 5c). This metamorphic stone is commonly quarried in the Levanto area (Liguria Region, Northern Italy; Blanco 1999).
It is worth to note that only the Giallo di Verona in the upper part of the façade is sculpted, due to its good workability, whereas the Carrara marble shows discoloration phenomena, most likely due to oxidation processes of the bronze letters placed on its surface.

\section{Stop 4: The Fountain of the Repubblica Square}

It was made by Diomede Catalucci in 1908 using a whitish-greyish crystalline fine-grained marble which is characterised by numerous grey carbonaceous veins (Fig. 6a), typical of the commercial variety known as the Carrara Bianco Venato (Apuan Alps, Tuscany Region; Carmignani et al. 2007). The slabs of the eight sides of the basin show clear discolouring phenomena marked by yellowbrownish areas (Fig. 6b). These weathering processes, generally affecting the white marbles, are probably due to porosity and compositional differences (e.g., the presence of small sized accessory iron oxide/sulphide minerals or organic material; Bams and Dewaele 2007; Selbekk et al. 2012). In a fountain, the moisture and the water 
Fig. 6 Stop 4: the fountain of the Repubblica Square (a) and the staining phenomena occurring on the Venato variety of Carrara marble (b)
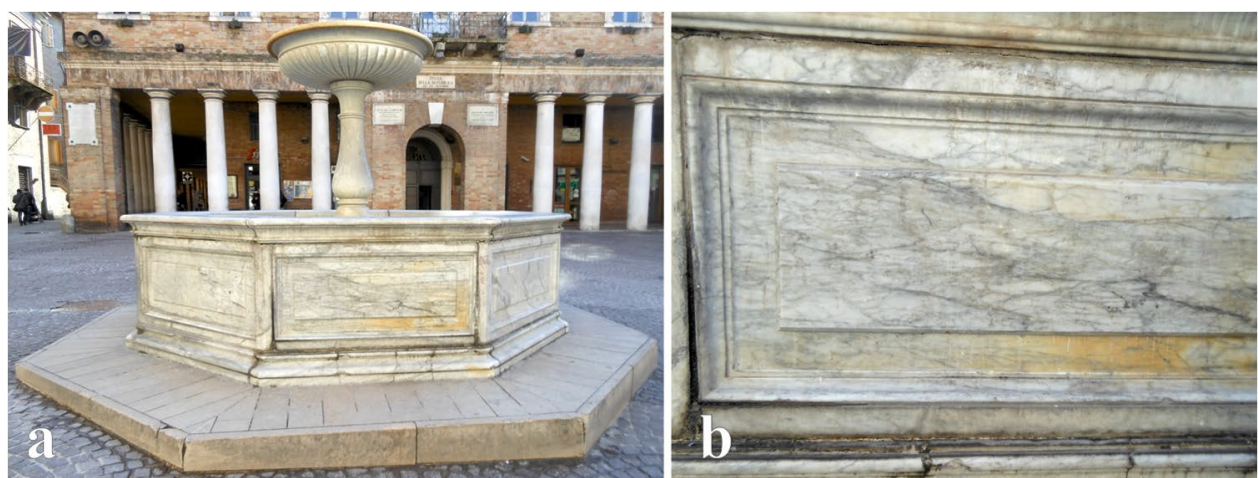

can easily lead, very fast, to discolouring processes. The fountain was removed from its original position in 1927 to facilitate the traffic of the centre of Urbino. Then, it was restored and relocated in its original position in the nineties of the last century.

\section{Stop 5: The Roman Walls}

From more than 2500 years ago the Il Poggio area (the Southern hill of the historic centre of Urbino; Fig. 2) was inhabited at first by unknown populations and successively by the Galli Senoni from the fourth century BC, and later by the Romans from 285 BC up to 476 AD (Mazzini 1982). During the Roman period, Urbino (Urvinum Mataurense) played a fundamental military role and therefore massive defensive walls were built (Luni 1993). Although some stretches of these walls are still visible, they underwent several destruction phases, and some big ashlars were reused for more recent architectural structures. A well-preserved small stretch of the Roman walls is along via Budassi (Fig. 7a, this stop). According to the construction style (opus quadratum), the walls should date back to third and second century $\mathrm{BC}$, and are constituted by dry stacked big, squared stones (i.e., ashlars), which are about two Roman feet thick (ca. $60 \mathrm{~cm}$ ) and two or two and half Roman feet long (ca. 60 or $75 \mathrm{~cm}$; Luni and Ermeti 2001). The most used rocks, also visible in other sites (Fig. 7b, c and Fig. 2 circled letters a and $b$ respectively), are represented by the limestones of the Bugarone Group, probably coming from the quarries located in the Furlo area (Monte Pietralata-Monte Paganuccio anticline) or in the Monte Nerone area (Fig. 8). Other frequently used ashlars consist of calcareous tufas, probably coming from the Upper Pleistocene alluvial terrace scarps located along the Metauro River (Fig. 8). These deposits could have been formed at the boundary between alluvial sediments and the underlying impermeable bedrock, where contact springs occur (Busdraghi and Veneri 2003). A minor amount of local sandstones (e.g., Marnoso-Arenacea Formation Auct.; Conti et al. 2020 and references therein) and

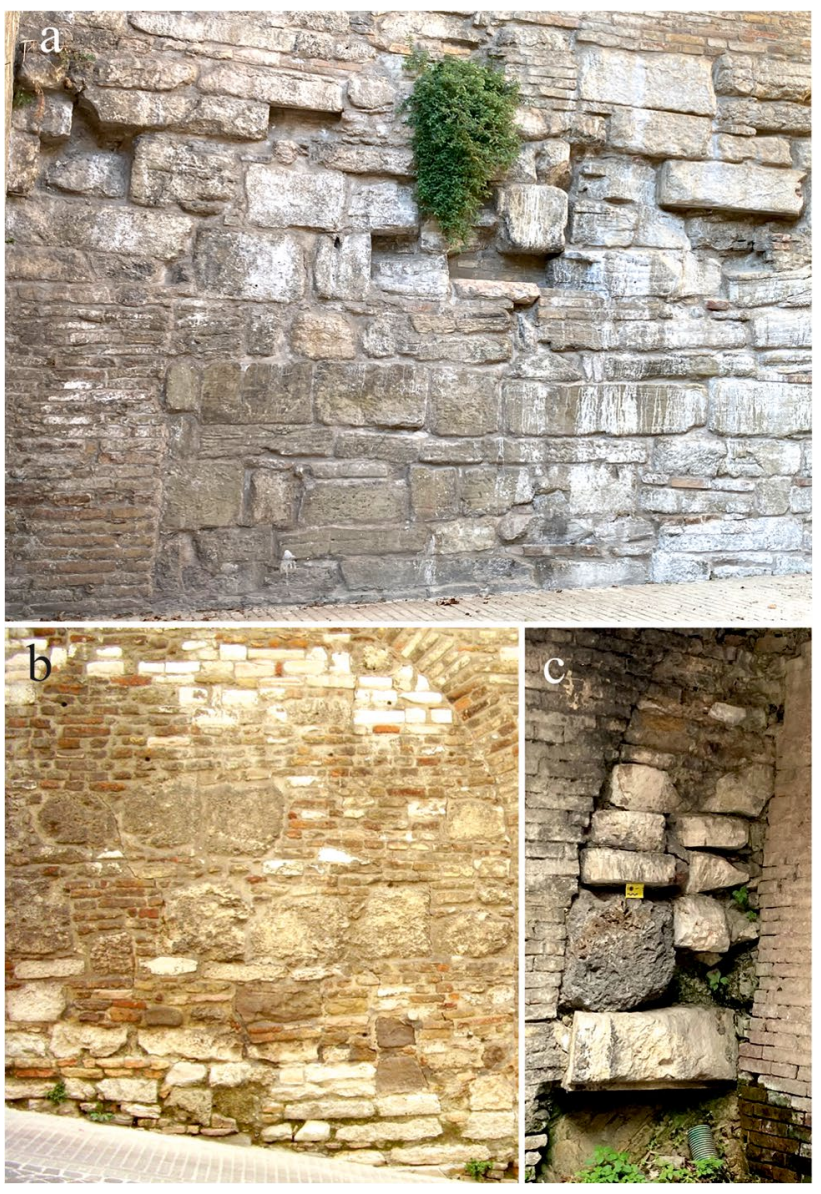

Fig. 7 Stop 5: the unique exposed remnants of the Roman walls (via Budassi) constituted by big ashlars of travertine, nodular limestone and sandstone (a), and more recent urban fabric, via Saffi (b) and Corso Garibaldi (c), also indicated in Fig. 2 (circled letters a and b respectively) where reused Roman ashlars are present

laminated clastic balatino gypsum (Gessoso-Solfifera Formation Auct.; Conti et al. 2020 and references therein) can be also recognised (Fig. 8). 


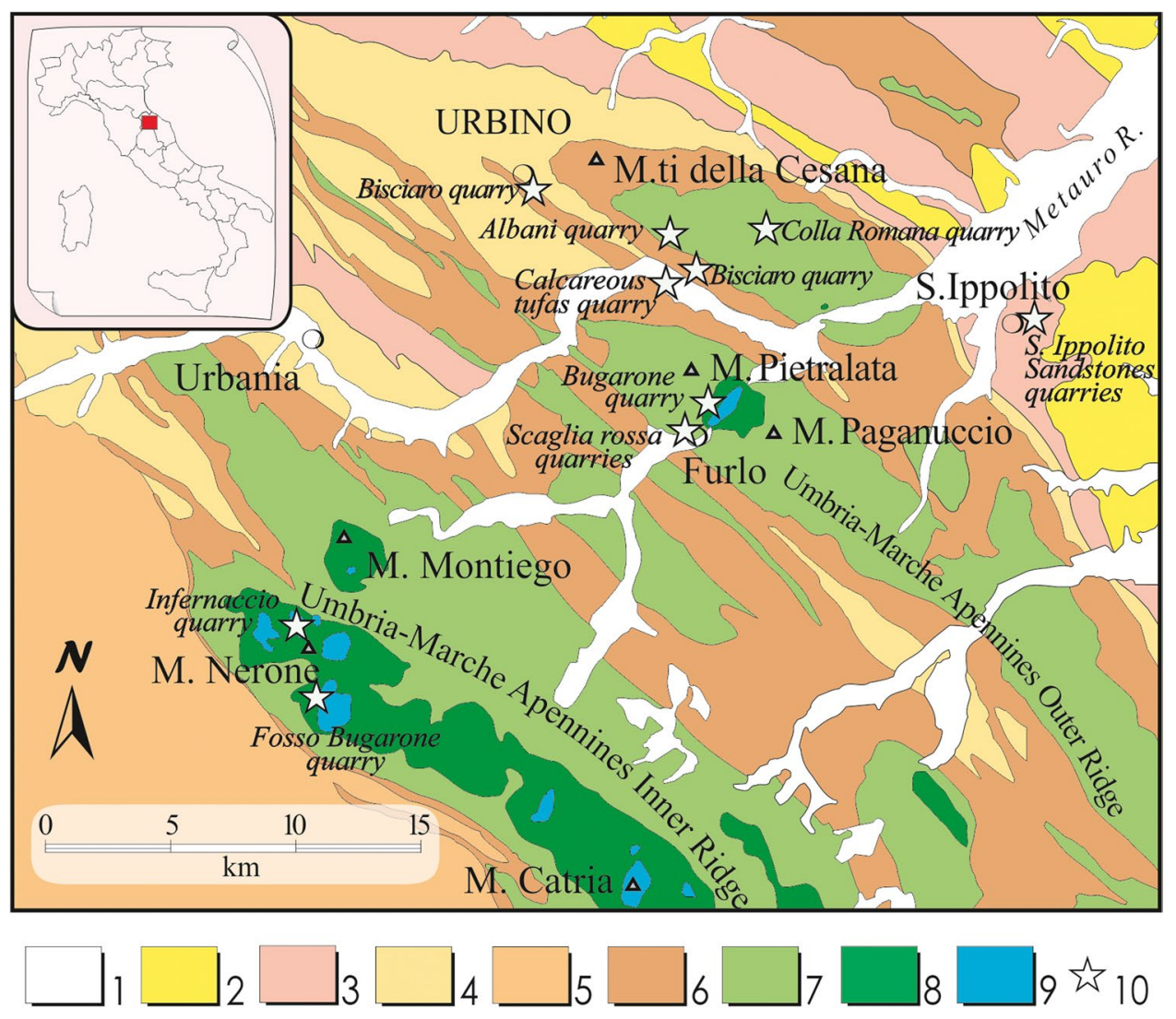

Fig. 8 Geological sketch of the Umbria-Marche Apennines comprising the Umbria-Marche-Romagna Succession (Conti et al. 2020 modified) with the location of the historical exploited quarries of the local sedimentary stones relatively close to the Urbino historic centre. Legend: (1) Quaternary gravel and sand fluvial deposits; (2) PlioPleistocene pelitic and arenitic marine deposits; (3) Gessoso-Solfifera and Colombacci Formations (Messinian evaporitic and terrigenous units); (4) and (5) Marnoso-Arenacea Formation: Tortonian (4) and

\section{Stop 6: The Façade of the Urbino Cathedral}

The Cathedral started to be built on May 20, 1439 (Negroni 1993), based on the original project of Francesco di Giorgio Martini. Unfortunately, some earthquakes have been responsible for frequent damages of the different sectors of the architectural structures, and therefore the works lasted more than three centuries. The completion of the church (façade included) was assigned to the architect Giuseppe Valadier after the collapse of the dome on January 12, 1789.

The most used lithotype for the Cathedral façade is represented by the calcareous rocks of the Jurassic Bugarone Group (Fig. 8), locally named Pietra del Furlo (Mazzini 1982; Negroni 1993). This stone shows a pale-grey (at places pinkish) colour (Fig. 9a, b) and contains clearly distinguishable macrofossils (e.g., large Ammonites, up to few decimetres in size; Fig. 9c, d). The provenance area can be referred to the Bugarone quarry of the Furlo area, historically named "Cava Alta" (at about 20 km from Urbino; Fig. 8). Slabs of
Langhian-Serravallian (5) turbidites; (6) Bisciaro and Schlier Formations (Lower-Middle Miocene marly limestones and marls); (7) Scaglia Bianca, Scaglia Rossa, Scaglia Variegata and Scaglia Cinerea Formations (Upper Cretaceous-Oligocene limestones and marly limestones); (8) Corniola, Calcari Diasprigni, Maiolica and Marne a Fucoidi Formations (Middle Jurassic-Lower Cretaceous limestones and marly limestones); (9) Calcare Massiccio Formation and Bugarone Group (Lower Jurassic limestones); (10) ancient quarries

the Bugarone Group were also used to pave the entrance and the 18 outdoor steps of the Cathedral and also part of the floor of the Duca Federico Square (between the Cathedral and the entrance of the Ducal Palace; Fig. 9c, d).

\section{Stop 7: The Façade of the Ducal Palace}

Symbol of the Italian Renaissance, it was mainly built using bricks through several stages, starting from the fifteenth century (1455; Mazzini 1982) under the direction of the architects Maso di Bartolomeo, Luciano Laurana and Francesco di Giorgio Martini. The façade, including the main entrance located in Duca Federico Square, is decorated by rusticated limestone slabs with five large sculpted framed portals (Fig. 10). The used stone can be referred to the Calcare Massiccio Formation consisting of white, well lithified and, at places, oncolitic limestone facies, termed Travertino del Monte Nerone by Baldi (1580). The term travertino is of course inappropriate and wrong for the 
Fig. 9 Stop 6: the façade of the Cathedral mostly made of lithotypes of the Bugarone Group (a) characterised by degradation phenomena of detachment and staining due to pyrite oxidation (b); particulars of the square adjacent to the Cathedral, paved with bricks and blocks of the Bugarone Group characterised by big fossils of Ammonites $(\mathbf{c}, \mathbf{d})$
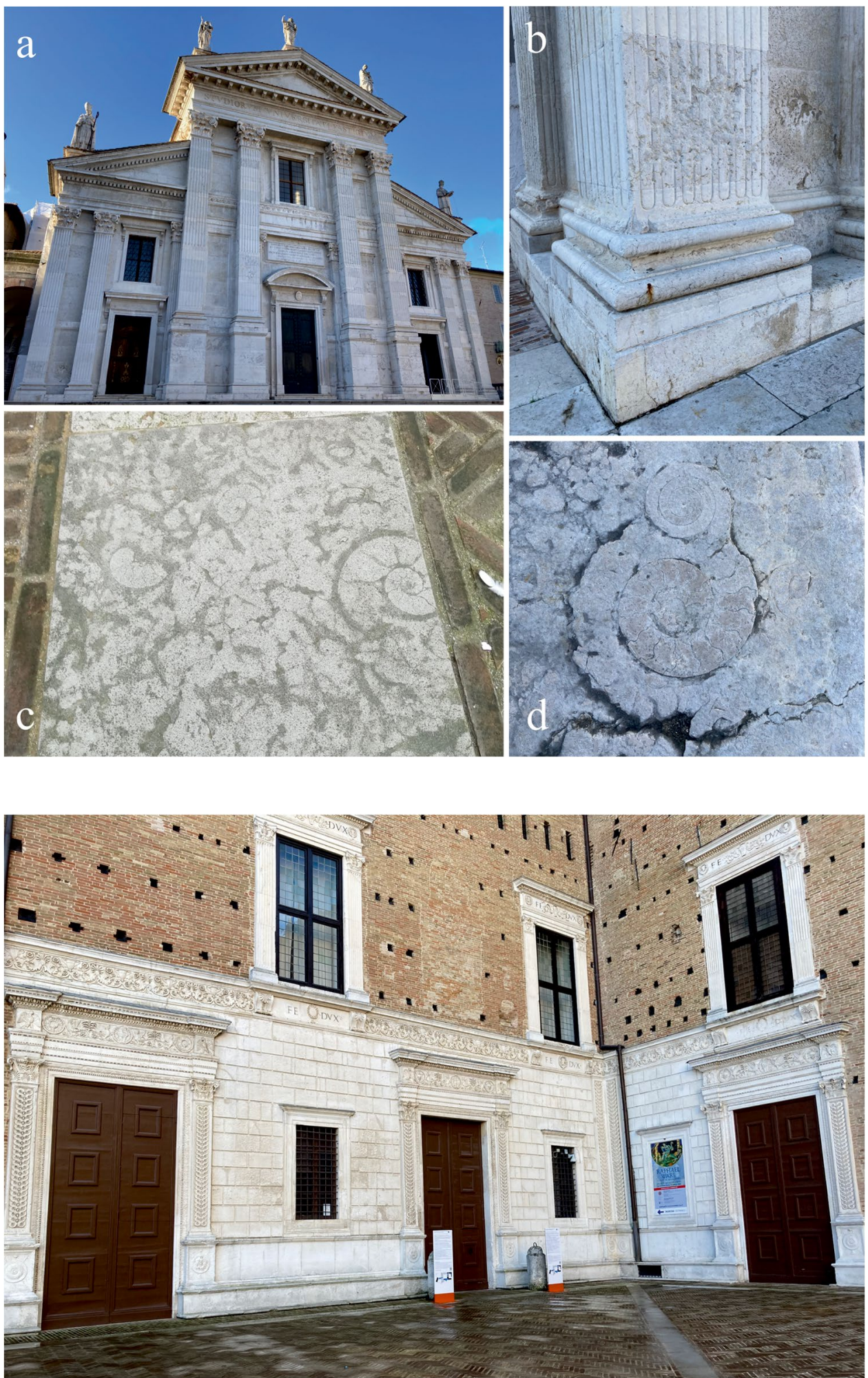

Fig. 10 Stop 7: the partially panelled façade of the Ducal Palace and three of the five sculpted entrances, all made using the Calcare Massicio Formation
(Fig. 8) were used for several sculpted panels, the famous tiles depicting war machines by Francesco di Giorgio Martini (currently removed), which decorated the backrests of the seat running along the façade. 


\section{Stop 8: The Portal of the Oratorio delle Grotte}

The oratory was founded in the sixteenth century within three chapels located in the undergrounds of the Cathedral. Its entrance on the left side of the Cathedral itself was decorated in 1621 by a portal made by the architect/sculptor Bartolomeo Ammannati, using blocks of calcareous tufas (Fig. 11a). This stone is known with the popular name of Pietra Spugna or Pietra Sponga because of its spongy/ porous appearance (Rodolico 1953), and it was also used to create cave-like spaces in the interior of the Oratorio itself. The blocks of the portal show the typical structure of the calcareous tufas, represented by carbonate encrustations of vegetation such as reeds, frustules and leaves (Fig. 11b, c). Bartolomeo Ammannati considered the calcareous tufas a highly valuable geomaterial, and he used the same lithotype in the portal of the Oratorio della Morte, which is located in a little square on the right side of the Cathedral (Fig. 2, circled letter c). This stone is very similar to the large blocks constituting some remains of the Roman walls (see stop 5). Although an extra-regional provenance (Umbria Region) cannot be ruled out, it is worth noting that near Urbino an active deposition of calcareous tufas along the Metauro River (Busdraghi and Veneri 2003) is still present (Fig. 8).

\section{Stop 9: The Egyptian Obelisk}

This exotic and unusual monument is the unique Egyptian obelisk among the regions of the Adriatic coast (i.e., to the East of the Apennine Chain) and it is constituted by an igneous intrusive rock, characterised by a medium- to coarse- grain size (Fig. 12a, b). It is a holocrystalline granite with large pink K-feldspar, white plagioclase, interstitial vitreous quartz and randomly disposed mafic minerals (biotite, amphibole and opaques). All these compositional and structural features, coupled with the Egyptian origin of the obelisk, helped us to identify the stone as the Pink Assuan Granite (from Southern Egypt; Borghini 1998). Similarly, to the other Egyptian "obelisks in exile" (as defined by Iversen 1968) located in Italy (Roma, Firenze, Benevento and Catania), also the Egyptian obelisk of Urbino (about $4.90 \mathrm{~m}$ high) comes from the Assuan (ancient Siene) quarries. Differently with respect to the other ones, it consists of five pieces coming from some obelisks paired with those currently present in the Piazza della Minerva and Piazza del Pantheon (Roma; Donadoni 2001). All the fragments of the Egyptian obelisk of Urbino were manufacted around the 580 BC (Curto 1965), transported to Roma (90 BC) and located together with other monuments in the Iside and Serapide shrine (Iseo Campense in the Campo Marzio), which was a temple dedicated to the Egyptian divinities (Curto 1965; Donadoni 2001; Barberini and Fei 2017). Discovered between the fourteenth and seventeenth century, in 1702 the Gesuites offered some of these granite blocks to the Cardinal Annibale Albani who in turn, in 1737, gave them to the city of Urbino, the hometown of his uncle Pope Clemente XI (Giovanni Francesco Albani; Curto 1965; Donadoni 2001; Barberini and Fei 2017). This donation, as well as that of other numerous manufacts and ornamental stones, is well documented by Tosi (1753). In particular, as regards the obelisk this author wrote that Cardinal Annibale Albani managed for locating the Egyptian monument (Guglia) in front of the San Domenico Church: "Avanti la chiesa di San Domenico fece alzare una Guglia, con piedistallo fatto d'un pezzo, con quattro colonnette intorno, e detta Guglia è pietra d'Egitto, con inscrizioni Caldee, ed in cima vi è tre monti, una stella, ed una Croce con entro
Fig. 11 Stop 8: the Oratorio delle Grotte portal (a) and some details of the used calcareous tufas or Pietra Spugna $(\mathbf{b}, \mathbf{c})$
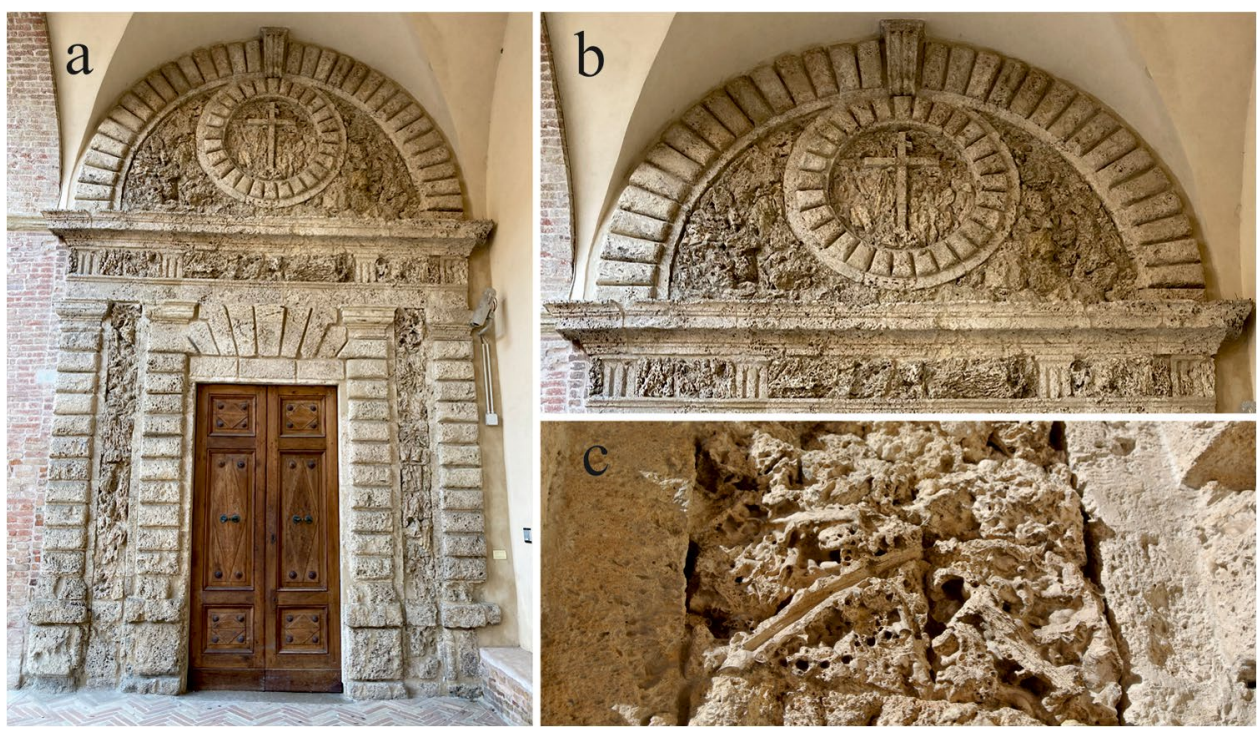
Fig. 12 Stop 9: the Egyptian obelisk (a) with a particular of the Pink Assuan Granite and of the basement characterised by the oncolitic facies of the Calcare Massiccio Formation (b)

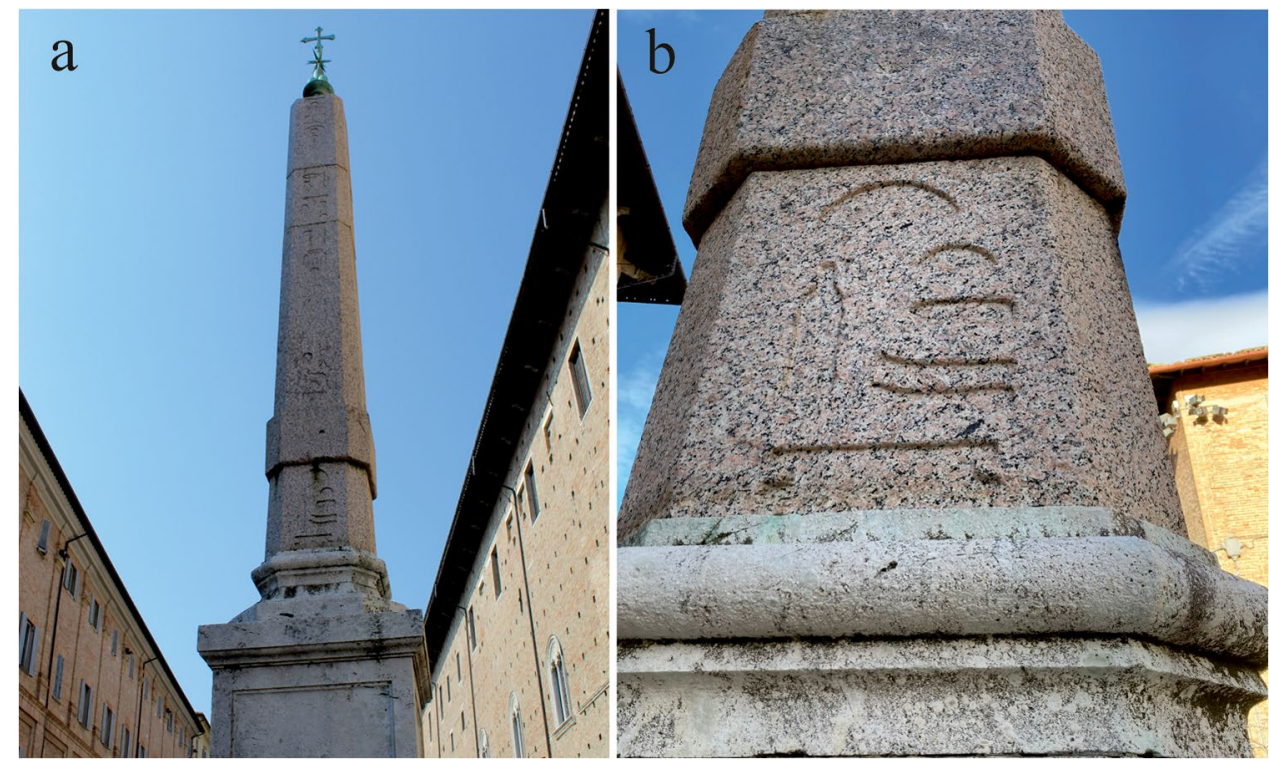

varie reliquie, il tutto di bronzo" (Tosi 1753). However, some modifications and/or misunderstandings were carried out during the assemblage of the five fragments (Fig. 12a; Curto 1965; Donadoni 2001). In fact, the obelisk of Urbino shows rounded off corners, one block overturned and another one, characterised by larger dimension, without hieroglyphs (Fig. 12a, b). Finally, the crest of the Albani family was placed on the clipped top.

The basement and the four little pillars are made of the Calcare Massiccio Formation, showing a straightforward white oncolitic facies (Fig. 12b).

It is worth to note that in its manuscript, Tosi (1753) describes "another column made of Egyptian stone placed on a fine sculpted white marble basement and the San Crescentino small bronze statue on the top, located in the little square in front of the Northern façade of the Palazzo Pubblico" now called Largo San Crescentino (Fig. 2 circled letter d). Nevertheless, in this place, a white marble column is now present (always with the same basement and San Crescentino statue on top) instead of the Egyptian stone column. Curiously, the monument described by Tosi's manuscript would resemble that in a photographic reproduction of the beginning of twentieth century located in the 8 Settembre Square (nowadays Repubblica Square; see stop 4), where a column, which seemed to be (from that photo) about $40 \mathrm{~cm}$ in cross section diameter, really looked like a granite, i.e., Egyptian stone but is not present anymore in the Repubblica Square. It would be of paramount historical importance to know what happened to this additional Egyptian stone column and if it was eventually reused. We can finally observe, among the rare ornamental elements made of granites in Urbino, the two little pillars made of fine-medium pale-pinkish/whitish granitic stone, at the entrance of the Episcopal Palace near to the Cathedral.

\section{Stop 10: The Porta Valbona}

This monumental main entrance of the city was built in 1621 for the marriage of Federico Ubaldo della Rovere and Claudia Medici (Mazzini 1982). In the external part, it consists of large rusticated ashlars with two coupled monolithic half columns on each side. In the upper part, there is a frieze with the inscription commemorating the wedding, and a curved and broken tympanum (Fig. 13a). The used material is a yellowish sedimentary terrigeneous rock consisting of fineto medium-grained sandstones (Fig. 13a, b) with abundant content of bioclasts. Even if the original quarries are hardly recognisable because of their abandonment, the stones of the Porta Valbona match with Sant'Ippolito Sandstones (Colombacci Formation, Fig. 8), which were largely used (Fig. 2 see symbols of portals, pillars and colums) in several monumental portals of the historic centre of Urbino (Santi et al. 2019). It is worth to note that, since the fourteenth century, skilful stonemasons from Sant'Ippolito were present in Urbino, importing the stone raw material from that area about $20 \mathrm{~km}$ ESE of the city (Fig. 8). The large carved blocks and the big monolithic columns of the Porta Valbona testify a good availability of this lithotype in the past. Two large eagles (Fig. 13a, c), made of the white oncolitic facies of the Calcare Massiccio Formation (Fig. 8), were added to the monument during the eighteenth century.

\section{Geological Setting of the Umbria-Marche Apennines and the Local Sedimentary Stones Used in the Urbino Historic Centre}

The city of Urbino is located in the Eastern sector of the Umbria-Marche Apennines (Central Italy), which is a foldand-thrust mountain belt (Conti et al. 2020, and references 
Fig. 13 Stop 10: the Porta Valbona, South-Western entrance of the historic centre of Urbino, made of the Sant'Ippolito sandstones $(\mathbf{a}, \mathbf{b})$; detail of one of the two eagles sculpted in Calcare Massiccio Formation (c)

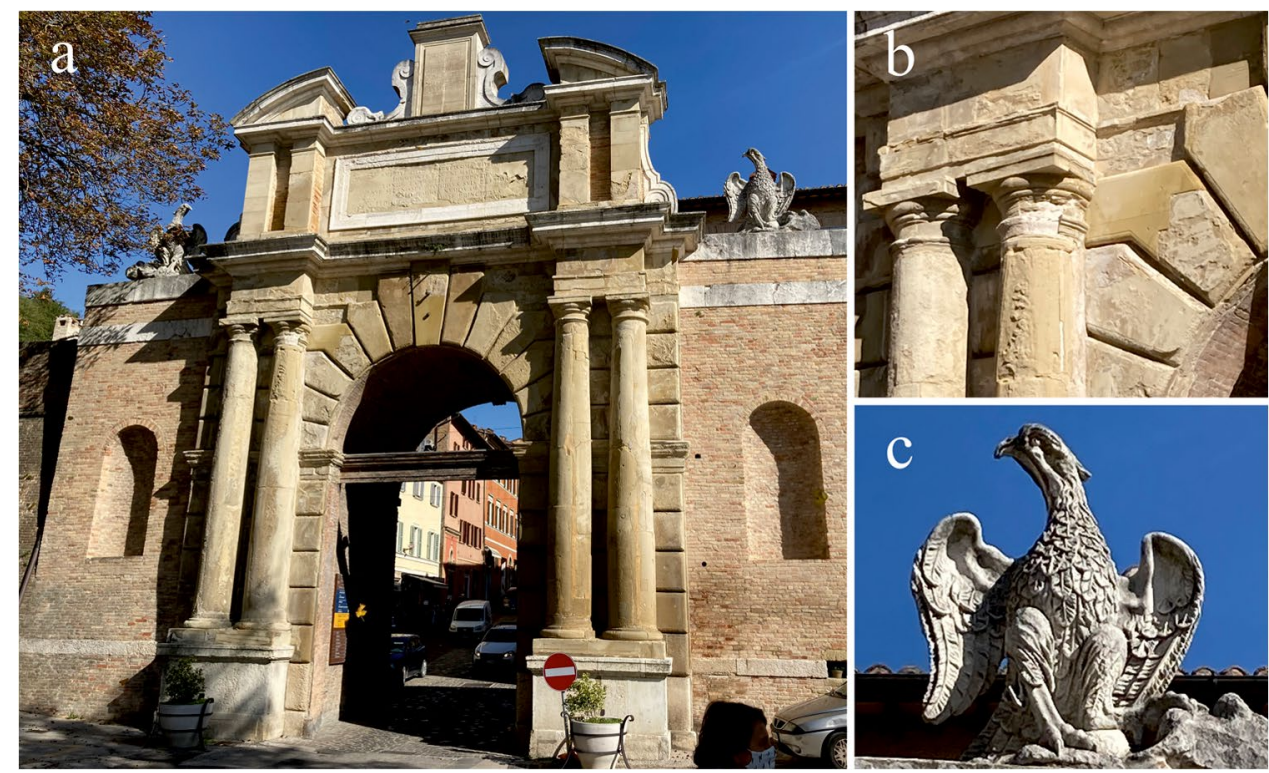

therein) characterised by a sedimentary suite (i.e., the UMRS, Fig. 8) extending from late Triassic up to the Pleistocene p.p.

The lower part of the succession is characterised by a carbonate platform deposition ending with the Calcare Massiccio Formation (Centamore et al. 1971; Marino and Santantonio 2010), consisting of about 700-m-thick massive limestones and covered by multi-layered carbonate pelagic deposits (Lias p.p.-Oligocene). The base of this cover is characterised by different Jurassic p.p. successions (Santantonio 1994; Morettini et al. 2002; Marino and Santantonio 2010; Donatelli and Tramontana 2012, 2014, and references therein): (i) the "structural high successions", which are mainly represented by the Bugarone Group (Santantonio 1994), and (ii) "the basin successions", which deposited through the stratigraphic interval extending from Corniola Formation to Calcari Diasprigni Formation. Both types of successions are topped by the calcareous Maiolica Formation, whose deposition continued during the Early Cretaceous p.p. (Centamore et al. 1986). The Early Cretaceous p.p.-Oligocene deposition (Centamore et al. 1986; Parisi 1989 ) is represented by a pelagic-emipelagic succession, which includes the Marne a Fucoidi Formation, the Scaglia Group (Scaglia Bianca, Rossa, Variegata and Cinerea Formations) and is constituted by limestones, cherty limestones and marls. During the Early Miocene the Bisciaro Formation (Aquitanian p.p.-Burdigalian p.p.) deposited, followed by the marly Schlier Formation. From the Middle Miocene, a clastic succession related to the evolution of a W-E migrating foredeep turbidite system (Marnoso-Arenacea Formation) developed (Cantalamessa et al. 1986; Guerrera et al. 2012, and references therein). Later, Messinian deposits (Gessoso-Solfifera Formation Auct. and different clastic units ) covered by the Pliocene-Pleistocene p.p. terrigenous succession (AA.VV. 2009, 2011a, b, 2014, 2016, b; Manzi et al. 2020; and references therein) formed.

The main lithological and petrographic features (macroscopic and microscopic) of the local sedimentary stones used in the historic centre of Urbino are reported below.

\section{Calcare Massiccio Formation}

The Jurassic Calcare Massiccio Formation (HettangianLower Pliensbachian p.p.) is represented by three lithofacies: Calcare Massiccio A, Calcare Massiccio B and Calcare Massiccio C (Petti et al. 2007; Marino and Santantonio 2010; Donatelli and Tramontana 2012; Penasa et al. 2019) deposited during different evolutionary stages of the Early Jurassic carbonate platform of the Umbria-Marche area. The Calcare Massiccio A (Calcare Massiccio del Monte Nerone, lower member; Centamore et al. 1986) consists of whitish metric massive limestone beds (thickness 3-4 to $15 \mathrm{~m}$ ), with oncoids and peloids. This unit forms a thick peritidal cyclotemic succession, which evolves into the lithofacies $\mathrm{C}$ and $\mathrm{B}$; these latter related to the progressive dismemberment and drowning of the originary carbonate platform due to the Jurassic extensional tectonics. The Calcare Massiccio A reaches a thickness of about $700 \mathrm{~m}$. The Calcare Massiccio C (Calcare Massiccio del Burano; Centamore et al. 1986) mainly consists of whitish-light brown massive limestones (bed thickness 4-5 m), with abundant $\mathrm{cm}$-thick oncoids and peloids. The maximum thickness is about $200 \mathrm{~m}$. The Calcare Massiccio B (Calcare Massiccio del Monte Nerone upper member; Centamore et al. 1986) shows a thickness usually of about $10-30 \mathrm{~m}$, and mainly consists of bioclastic massive or poorly stratified up to 2-m-thick generally light 
brown calcareous beds, with small-sized oncoids and a varying amount of peloids.

Some of the most exploited ancient (at present inactive) quarries (Fig. 8) of Calcare Massiccio Formation in the Northern Marche can be still recognised (AA.VV. 2007) in the Monte Nerone anticline area (Infernaccio quarry; Bani 1989). In this quarry, the Calcare Massiccio A is constituted by $(i)$ metric thick banks of very compact and well cemented limestones, which are characterised by macroscopic vacuolar structures (similar to those characterising a travertine rock) with ( $i$ i) interbedded white, poorly cemented and very porous beds. The most competent thicker beds are represented by coastal environment deposits. Carbonate grains are almost entirely represented by peloids with associated little rare oncoids, benthic Foraminifera and aggregate grains (Fig. 14a, b). Rare calcareous algae and Gastropods remnants also occur (Magi 2012). The historical and popular language addressed to both architectural and restoration contexts named the Calcare Massiccio lithofacies as Travertino maschio (hard) and Travertino femmina (soft), respectively (see stop 7). The former mentioned lithofacies was also named Travertino di Piobbico or Travertino del Monte Nerone (Baldi 1704; Selli 1954). Of course, the term travertino is wrong for a correct geological classification of this limestone because it must be referred correctly only to a sedimentary rock due to chemical carbonate precipitation from ground and surface waters or hot springs, under subaerial conditions, which is not the case of the Calcare Massiccio Formation.

\section{Bugarone Group}

This Jurassic unit corresponds to the Bugarone Formation Auct., and is a thin (maximum $50 \mathrm{~m}$ ) fossil-rich condensed succession resulting from Pelagic Carbonate Platform environment deposition (PCP, sensu Santantonio 1994) above the Jurassic structural high areas (Cecca et al. 1990; Cecca and Macchioni 2004; Donatelli and Tramontana 2014; Lundblad 2019; Romano et al. 2019). In particular, in the Fosso Bugarone (Fig. 8), the 16-m-thick-type section of the Bugarone Formation (i.e., the previous stratigraphic rank of unit), was measured by Centamore et al. (1971). The Bugarone Group (Toarcian p.p.-Tithonian p.p.) consists of bioturbated, more or less dolomitized, nodular limestones with greenish marl intercalations with fossil fragments, and horizons containing peloids and ooids (Fig. 14c). Fossils are mainly represented by wellpreserved, sometimes large-sized, internal moulds of Toarcian Ammonites. The latter is a distinctive feature of the Bugarone Group whose lithotypes frequently characterise the stone slabs used in the building façades (see stop 6) and for the stone-paved streets of the historic centre of Urbino (e.g., portico of Corso Garibaldi, Fig. 2, circled letter b). The fossil assemblage also includes shells of Gastropods, Echinoderms and abundant Brachiopods. In addition, limonitized pyrite nodules are rather frequent. In the Northern Marche, some ancient quarries, which are at present inactive, are recognisable in the Monte PietralataMonte Paganuccio anticline (Bugarone quarry, Furlo area, Fig. 8 and Fig. 14c) and in the Monte Nerone anticline (Fosso Bugarone quarry, Fig. 8).

\section{Scaglia Bianca and Scaglia Rossa Formations}

The Scaglia Bianca Formation (Upper Albian p.p.-Early Turonian) consists of white to light grey micritic limestones (Fig. 14d) with beds ranging from 10 to $30 \mathrm{~cm}$ in thickness, and containing pinkish to black chert layers, lenses and nodules (Coccioni and Galeotti 2003; Lanci et al. 2010). A typical about 1-m-thick anoxic interval with black shales (the well-known Bonarelli level; Bonarelli 1891; Arthur and Premoli Silva 1982; Donatelli et al. 2010, and references therein), characterises the upper portion of this formation, close to the boundary with the more recent Scaglia Rossa Formation. This latter (Lower Turonian p.p.-Lutetian p.p.) is generally constituted by regular beds of pinkish and reddish limestones (Fig. 14e), ranging from 10-15 cm to about $30 \mathrm{~cm}$ in thickness, and interbedded few millimetres thick reddish marls (Centamore et al. 1975, 1979; Arthur and Fischer 1977; Wezel 1979; Tonelli et al. 2019). In the lower and the upper part of the formation, limestones are characterised by beds and nodules of red chert, while the middle-upper portion is marked by the occurrence of marly-rich lithofacies. Moreover, some ivory-white very fine- to mediumgrained bioclastic intercalations are also present, in some stratigraphic intervals (e.g., in the Furlo and in the Monti della Cesana anticlines; Capuano et al. 1994). When these layers are used as building stones (e.g., in masonry buildings), they can be easily confused with the Scaglia Bianca Formation, due to the atypical white colour.

In the Renaissance period, the Scaglia Bianca and Scaglia Rossa Formations were particularly appreciated for ornamental use, such as coats of arms, fireplaces, portals, windowsills, and stairways as those realised in the interior of the Ducal Palace and numerous buildings of Urbino (Fig. 2, see symbols of portals, pillars and colums). The ancient Colla Romana and Albani quarries (AA.VV. 2007), identified in Monti della Cesana anticline near Urbino (Fig. 8), were active since the Roman times. In particular, in the Albani quarry the outcrops show an attitude of beds which is favourable to an easy exploitation. In addition, other ancient quarries were localised in the Furlo area (about $20 \mathrm{~km}$ from Urbino) mainly along the Southern limb of the Monte Pietralata anticline (Fig. 8). 
Fig. 14 Thin section petrography of the most representative facies of the described local sedimentary stones (plane polarised light). Calcare Massiccio A (a, b): limestone with oncoids and rare remnants of calcareous Algae, Gastropods and benthic Foraminifera (i.e., Travertino Maschio) (a) and limestone with peloids, oncoids, coated grains and benthic Foraminifera (i.e., Travertino Femmina) (b); Bugarone Group: nodular limestone with Ammonites, filaments, Radiolaria and planktonic Foraminifera and some little opaque crystals of pyrite (c); Scaglia Bianca Formation (d) and Scaglia Rossa Formation (e): micritic limestones with planktonic Foraminifera; Bisciaro Formation: marly limestone with Radiolaria and Foraminifera (f g); Sant'Ippolito Sandstones (facies of the Colombacci Formation): bioclastic sandstone with planktonic and benthic Foraminifera (h)

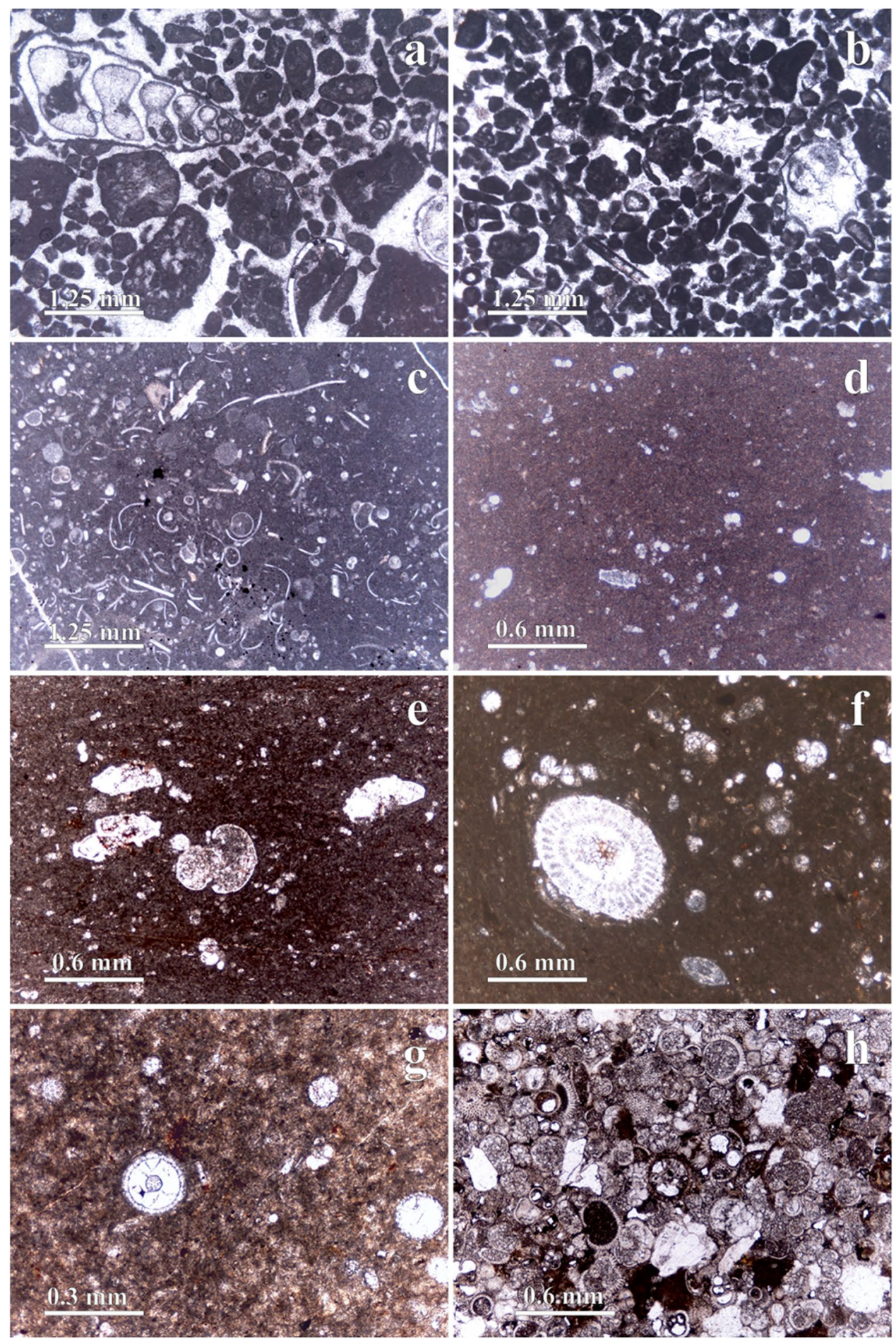

\section{Bisciaro Formation}

The Bisciaro Formation (Aquitanian p.p.-Upper Burdigalian) is represented by a marly limestone succession (Guerrera et al. 2015) consisting of alternating greyish limestones and marly limestones, grey marls, calcareous marls and clayey marls. In the lower portion of the unit, bands and/ or nodules of black or grey chert and cherty limestones are frequent. The formation is also characterised by numerous thick volcaniclastic beds (Guerrera et al. 2015). The Bisciaro Formation shows an extremely variable lithostratigraphy mainly depending to the palaeogeography of the depositional basin. The thickness ranges from 20 to $100 \mathrm{~m}$ in the different sectors of the Umbria-Marche-Romagna area. The main used lithotypes of this formation were limestones and cherty limestones (Fig. 14f, g), usually coupled with 
bricks (alternating two brick stripes courses each stone row, Fig. 15) as in the ancient Roman masonry building technique of opus vittatum. The use for the Urbino walls (AA. VV. 2007) can be observed especially since nineteenth century, probably introduced by Giuseppe Valadier's workers, during the Cathedral restoration (see stop 6). According to Valadier, this building technique could better withstand the seismic actions (Della Torre et al. 2019). Typical black chert lenses and nodules may locally characterise the used ashlars, so contributing to easily recognise the Bisciaro Formation. Due to its easily crushability not suitable for regular slabs, the Bisciaro Formation is employed for foundations, retaining walls (Corso Matteotti, Fig. 2, circled letter e) or for modest rural buildings. In the Urbino area, this formation is about $70 \mathrm{~m}$ thick and crops out extensively near the historic centre (Fig. 8) and in correspondence of the Southern limb of the Monti della Cesana anticline. Evidences of past quarry activities are still recognisable (Fig. 8).

\section{Sant'Ippolito Sandstones (Colombacci Formation)}

The Colombacci Formation (Upper Messinian, Savelli and Wezel 1978; Tramontana et al. 2005) is represented by siliciclastic deposits and consists of grey to ochraceous laminated pelites and silts, as well as subordinate thin bedded, fine-grained laminated sandstones. In the Sant'Ippolito area (about $20 \mathrm{~km}$ ESE of Urbino), a Colombacci Formation facies (Fig. 8), locally named Sant'Ippolito Sandstones, is characterised by medium to thick, frequently amalgamated beds of medium to coarse-grained, graded and laminated sandstones with pelitic and more rarely conglomerate intercalations. Most of the sandstones used in the historic centre of Urbino for several monumental portals of buildings (Santi et al. 2019) come from this area. They can be considered as lithic arenites and a very distinctive feature is the high content of bioclastic components (planktonic and benthic Foraminifera, shells of Gastropods, Bivalves and rarely brachiopods; between 80 and 90\%; Fig. 14h) with respect to the siliciclastic fraction (up to $10 \%$ ). The area of Sant'Ippolito is known as the provenance site of these stones also for its historical stonemason activity dating from the fourteenth century to as late as the beginning of the nineteenth century. Potential ancient exploited areas were identified in the hills surrounding Sant' Ippolito, where typical quarry-related shapes (scarps and steps too linear to be considered of natural origin) are still recognisable (Fig. 8; Santi et al. 2019). In particular, the portal of the Palazzo Ubaldini-Ivarra (Fig. 2, circled letter f), dating back to the fifteenth century, stands out for its exceptionally elegant manufacturing. It is worth to note that in this palace the lateral piers were sculpted with the same decoration that characterises the five portals of the adjacent Ducal Palace and the architrave shows the Spanish Ivarra family inscription. The Sant'Ippolito sandstones were also used to build the monolithic columns of the entrance of the Santa Maria della Misericordia old Hospital (Santi et al. 2019) dating back to the fifteenth century (Fig. 2, circled letter $\mathrm{g}$ ).

\section{Travertines and Calcareous Tufas}

Travertines are freshwater carbonates deposited by chemical precipitation from calcium bicarbonate-rich waters under subaerial conditions in a large variety of continental depositional and diagenetic settings (Capezzuoli et al. 2014, and references therein). Typically, the name travertine indicates a compact white to beige hydrothermal hot-spring deposit (stromatolitic travertines, see stop 2). However, some particularly porous varieties of this rock, which form with a limited extension from cold springs (Pedley 1990), should be more correctly termed as calcareous tufas (or phytohermal travertines). Cool freshwater calcareous tufas require the presence of macrophytes in addition to cyanobacteria, heterotrophic bacteria and algae, as long as the temperature remains below $30^{\circ} \mathrm{C}$ allowing the survival of these organisms. The water temperature considered as an indicator of shallow vs. deep-water circulation (and consequently deposition of travertines vs. calcareous tufas) is however a simplification, and an integrated approach would be necessary to understand and interpret the depositional environment. In fact, textures, mineralogy and geochemistry of deposits, the
Fig. 15 Walls built using a banded technique alternating brick courses and Bisciaro blocks (a) and a relative close up (b). See Fig. 2 for location
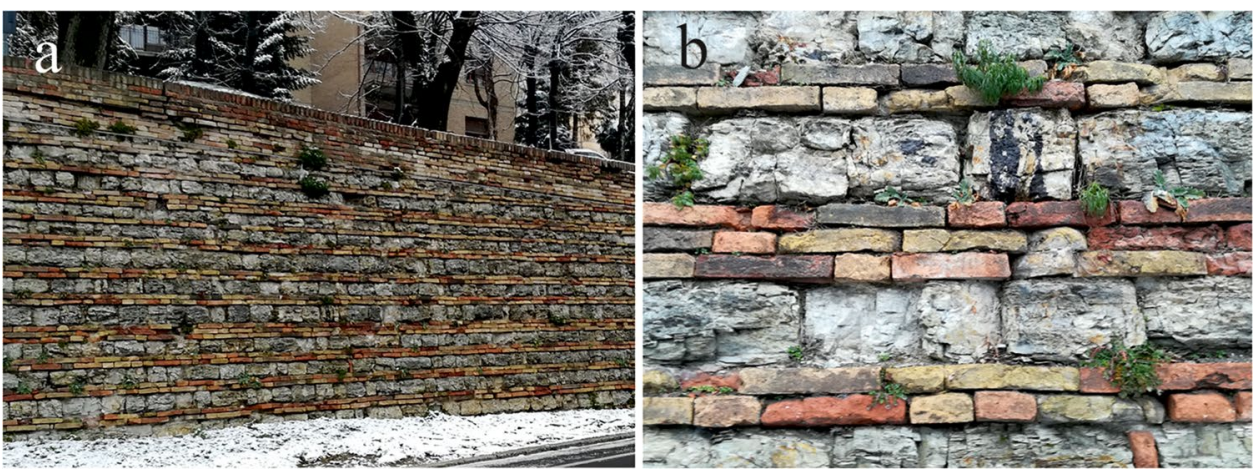
associated biota and the chemistry of waters from which they formed, as well as the geomorphological, hydrogeological and tectonic settings should be considered (Capezzuoli et al. 2014, and references therein). Calcareous tufas are locally named as Pietra Spugna or Sponga (Rodolico 1953), due to their low unit weight and very porous appearance. During the Roman period large ashlars $(59 \times 59$ or $59 \times 74 \mathrm{~cm})$ of calcareous tufas were extensively used in the historic centre of Urbino to build the defensive dry-stone walls (opus quadratum, see stop 5). Only a few remains of these walls are still preserved, mostly as a part of the urban Roman fabric. Nevertheless, it is also possible to observe ashlars of calcareous tufas as reused material in some buildings of more recent periods (e.g., via Saffi and Corso Garibaldi, Fig. 2, circled letters a and b respectively, and Fig. 7b, c). Furthermore, this lithology was also used (or reused) as decorative stone in some portals of Urbino, such as in the Oratorio delle Grotte (see stop 8) and in the Oratorio della Morte (Fig. 2, circled letter c), and as ornamental stone all around the Federico Brandani's putty sculpture of Nativity in the Oratorio di San Giuseppe (Fig. 2, circled letter h).

The calcareous tufas were hypothesised to have a local provenance (Luni 1985; Busdraghi and Veneri 2003), from the Upper Pleistocene alluvial terrace scarp of the Metauro River, where contact springs are present in correspondence with the boundary separating alluvial deposits from the impermeable bedrock (Fig. 8). At present, calcareous tufas continue to form here, and the challenge to find morphological evidence of ancient quarrying activity on such continental freshwater carbonates is still open. Nevertheless, a provenance of these building materials from non-local quarries cannot be ruled out, as historical evidence of massive exploitation of calcareous tufas is present in several areas of the adjacent Umbria Region (Silvestri 1977).

\section{Some Other Local Building Stones}

Other stones coming from both the UMRS and successions of adjacent areas (e.g., Tuscany, San Marino Republic, etc.) can be recognised throughout the historic centre of Urbino. Although not comprehensive of all the rocks that can be found in the city, we are going to mention some lithotypes not described in the previous sections. Large ashlars made of a local Messinian laminated clastic gypsum (balatino gypsum; Manzi et al. 2005) belonging to the Gessoso-Solfifera Formation Auct. (Fig. 8) were occasionally employed in the Roman walls and reused in some buildings starting from the Medieval period (e.g., Palazzo Peroli and Palazzo Battiferri, Fig. 2 circled letters i and 1 respectively). Other lithotypes from the UMRS (limestones of the Maiolica Formation, cherty limestones of the Calcari Diasprigni Formation, and sandstones of the Marnoso-Arenacea Formation, Fig. 8) have been also used. Lithotypes from the areas nearby Urbino
( San Marino and Monte Morello Formations, the Pietra Paesina and other rocks from the Val Marecchia Nappe; de Capoa et al. 2015) can be found along some ancient cobblestones of the historic centre of the city. By contrast, the flagstones constituted by extra-regional volcanic/subvolcanic grey to dark-red porphyry, which are recognisable along some stretches of the city, can be only referred to a modern use (twentieth to twenty-first centuries).

\section{Stones Quality}

Concerning the physical-mechanical features, the used carbonate lithologies generally show good resistance properties and durability, even outdoor. We reported in Table 1 the literature data of the described formations, used in the historic centre of Urbino, for a comparative description.

The samples of the Calcare Massiccio Formation, all coming from the same quarry in the Monte Nerone (Infernaccio quarry, Fig. 8), show variable parameters due to the distinct structures of the different lithofacies: in particular, the so-called Travertino maschio shows very low range of porosity (3-8\%) and good values of uniaxial compressive strength (between 50 and $60 \mathrm{MPa}$ ). By contrast, the so-called Travertino femmina facies exibits much higher porosity values (20-28\%) and lower uniaxial compressive strength (30-35 MPa). Regarding the Bugarone Group samples, collected in the Furlo area (Bugarone quarry, Fig. 8), they show even better physical-mechanical parameters ( $n$ $1.1-2.5 \%$, Qu 80-120 MPa), with respect to the above Calcare Massiccio Formation facies, although they are characterised by a shelly nodular structure, leading anisotropy and structural discontinuity. The Scaglia Bianca and Scaglia Rossa Formations, despite showing relatively good physical-mechanical features (porosity between 0.5 and $4.5 \%$ and uniaxial compressive strength between 100 and $150 \mathrm{MPa}$ ), they are not suitable to be placed outdoor because of their low resistance to freezing processes, typical of the severe winter conditions of Urbino. Nevertheless, the widespread presence of these formations in the nearby areas of Urbino could explain their extensive use even outdoor for portals, columns and walls throughout the city and some rural masonries (Fig. 2). The competent beds of the Bisciaro Formation outcropping very close to Urbino (Fig. 8) have moderate mechanical parameters (porosity $1-11 \%$, uniaxial compressive strength 60-110 MPa) and resistance to weathering. A peculiar feature is represented by several sets of discontinuities affecting the rock, which are highlighted by oxidised coats, leading to fractured, splintered and easily crushable stone blocks which are therefore not suitable as polished and well-finished surfaces. The used sandstones in the historic centre of Urbino, deriving from the Sant'Ippolito area (Fig. 8), are characterised by a very variable physical and mechanical features passing from low to moderate 
parameters of porosity (4-38\%) and uniaxial compressive strength (12-27 MPa). Calcareous tufas, outcropping along the alluvial terrace scarp of the Metauro River (Fig. 8) show a very high porosity (37-57\%) with a very low dry unit weight values $\left(1.14-1.68 \mathrm{Mg} / \mathrm{m}^{3}\right)$ and uniaxial compressive strength between 2 and $8 \mathrm{MPa}$.

For all the studied local sedimentary lithologies, we also performed a non-destructive test directly on the buildings, using the Schmidt hammer to evaluate the indirect resistance (apparent uniaxial compressive strength, Qua, Table 1). As reported in Table 1, the Qua decreases from limestones (40-65 MPa) to sandstones (40-45 MPa) and calcareous tufas (30-45 MPa from ashlars of the Roman Walls and 30-35 MPa from blocks of the Oratorio delle Grotte portal).

\section{Concluding remarks}

The overview on the building and ornamental stones used in the historic centre of Urbino (UNESCO World Heritage) and the proposed open-air urban-geological itinerary emphasise two main groups of lithotypes of different origin: (i) local sedimentary rocks of the UMRS outcropping in the near Apennines and (ii) extra-regional (national and transnational) igneous, sedimentary and metamorphic rocks. Limestones and sandstones are widespread building stones in Central Italy due both to local availability and the fact that well-cemented or lithified sedimentary rocks could be used successfully as building stones (blocks and ashlars) or non-polished slabs and tiles.

Several factors such as the historical period and the artistic style, the aesthetic of architectural features, the economic and social importance of buildings and/or monuments influenced the different use of stones. In particular, the more competent beds of the Calcare Massiccio (i.e., Travertino Maschio) were particularly suitable and appreciated as building stone, also for outdoor artifacts, such as the monolithic columns of the Cortile d'Onore of the Ducal Palace of Urbino (Busdraghi and Wezel 2002). This facies is however not appropriate for a decorative use due to its high density and cementation degree. By contrast, the less competent lithofacies of Calcare Massiccio (i.e., Travertino Femmina) is characterised by a good workability and sculptability, and thus suitable for ornamental elements, as testified by many interesting artworks, such as the capitals of columns of the Cortile d'Onore of the Ducal Palace (Fig. 2). Nevertheless, this decorative lithotype of the Calcare Massiccio Formation can be easily altered by weathering, due to the high porosity values, and thus conservation strategies should be planned. Another local sedimentary stone, very widespread in the buildings of Urbino, as slabs, is represented by the white lithofacies of the Bugarone Group which is unfortunately characterised by the occurrence of pyrite grains responsible for oxidation stains (Fig. 9b). The weathering processes may strongly weaken these nodular limestones generating random detachments of small fragments (Fig. 9b) and, coupled with pollution, may give rise to dissolution processes and development of dark crusts. Concerning the Scaglia Bianca and Rossa Formations, they were widely used for ornamental elements also due to their homogeneous colour and their excellent sculptability. Nevertheless, it is worth noting that these formations (especially Scaglia Rossa), are not suitable to be placed outdoor because of their low resistance to freezing processes. The competent beds of the Bisciaro Formation, characterised by poor quality of the stones were however used in ordinary walls of the city, mostly due to the presence of a quarry very close to Urbino (Fig. 8). Sandstones from the Sant'Ippolito area were used for numerous portals of the historic centre of Urbino in the Renaissance buildings and later (Fig. 2). This choice was mainly due to the traditional presence of stonemasons from Sant'Ippolito as far back as the fourteenth century, who using this sandstone on the basis of its availability, aesthetic quality and good workability rather than suitable mechanical properties. In fact, weathering processes of Sant'Ippolito sandstones such as detachments, exfoliation and differential degradation, affect Porta Valbona (Fig. 13a, b) and several other portals throughout the city. Concerning the calcareous tufas, they were employed as blocks and ashlars in the Roman walls (Fig. 7) and for their spongy/porous appearance creating a cave-like aspect (Fig. 11).

Moreover, Urbino offers the possibility to appreciate very precious ornamental stones from the Alps and other sectors of the Apennines, France and Egypt (extra-regional marbles, ophicalcites, granites and coloured limestones, Fig. 2) in some palaces, places and monuments. The decoration of the city started in the eighteenth century thanks to the prominent Albani family who offers, in the name of Pope Clemente XI Albani, numerous decorative elements, slabs, colums and one obelisk to the city.

Finally, all these lithotypes could be considered a special "rock collection" for the fruition of the urban-geological heritage of Urbino, unravelling the relation of the city both with its territory as regards the local stones, and the complex historical, cultural, and commercial reasons leading to the use of the extra-regional ornamental stones. The main building and decorative stones found in the historic centre of Urbino has been described and located in the city map (both as stops of the itinerary and additional places, Fig. 2), thus contributing to understand the distribution in space and time of the different used geomaterials, with respect to the architectural framework. This is the first attempt to spread the knowledge of the urban-geological heritage of Urbino in a simple and informative way to be used for a policy aimed at increasing the geotourism. The proposed open-air stone itinerary should contribute to address tourists 
also towards monuments and palaces different from those of the Renaissance period. In this way, in collaboration with the city administrators, a quick response code system (QR code; e.g., Pica et al. 2018) matching the Urbino map and its monuments/sites with the building and ornamental stones of the open-air, urban-geological itinerary, is also planned. Additional brochures and geological maps could be also published, aiming at accompanying tourists from the building stones seen in the Urbino historic centre to the ancient exploited quarries in the near Apennines.

Aknowledgements We are also grateful to the Fondo Antico of the University of Urbino contributing to the bibliographic research. Two anonymous reviewers and the Editor in Chief are also acknowledged for the useful comments improving the paper.

Funding Open access funding provided by Università degli Studi di Urbino Carlo Bo within the CRUI-CARE Agreement. This work was financially supported by the University of Urbino Carlo Bo (Dipartimento di Scienze Pure e Applicate-DiSPeA), through the research funding project 2017 entitled "Valorizzazione del patrimonio lapideo nei Beni Culturali: un percorso alternativo nella fruizione del centro storico di Urbino" (Responsible F. Veneri).

Open Access This article is licensed under a Creative Commons Attribution 4.0 International License, which permits use, sharing, adaptation, distribution and reproduction in any medium or format, as long as you give appropriate credit to the original author(s) and the source, provide a link to the Creative Commons licence, and indicate if changes were made. The images or other third party material in this article are included in the article's Creative Commons licence, unless indicated otherwise in a credit line to the material. If material is not included in the article's Creative Commons licence and your intended use is not permitted by statutory regulation or exceeds the permitted use, you will need to obtain permission directly from the copyright holder. To view a copy of this licence, visit http://creativecommons.org/licenses/by/4.0/.

\section{References}

AA.VV. (2007) Provincia di Pesaro e Urbino, Programma Provinciale delle Attività Estrattive, $1^{\circ}$ Variante Parziale al PPAE e PEAE Volume C: Ricerca e studio storico sulla provenienza e utilizzo della pietra da taglio nel territorio provinciale, $91 \mathrm{pp}$

AA.VV. (2009) Carta geologica d'Italia alla scala 1:50.000, Foglio 279 Urbino e Note illustrative. ISPRA, Roma

AA.VV. (2011a) Carta geologica d'Italia alla scala 1:50.000, Foglio 268 Pesaro e Note illustrative. ISPRA, Roma

AA.VV. (2011b) Carta geologica d'Italia alla scala 1:50.000, Foglio 281 Senigallia e Note illustrative. ISPRA, Roma

AA.VV. (2014) Carta geologica d'Italia alla scala 1:50.000, Foglio 292 Jesi e Note illustrative. ISPRA, Roma

AA.VV. (2016a) Il palazzo Scolastico di Urbino: da Scuola XXVIII Ottobre a Scuola Giovanni Pascoli (1933-1955). Archivio di Stato di Pesaro, Sezione di Urbino, 9 pp

AA.VV. (2016b) Carta geologica d'Italia alla scala 1:50.000, Foglio 280 Fossombrone. ISPRA, Roma

Agnati U (1999) Urvinum Mataurense. In: Per la storia romana della provincia di Pesaro e Urbino. L'Erma di Bretschneider, 19-108

Amadori ML, Gramegna E, Raffaelli G, Schillaci F, Mangani F, Bachiocca I (2005) La facciata della chiesa di Santo Spirito in Urbino: dalle indagini scientifiche al restauro. Quaderni Di Scienza Della Conservazione 3:115-132

Amadori ML, Raffaelli G (2006) Le pietre della tradizione nell' architettura delle Marche settentrionali (Italia centrale): antiche cave e dati petrografici delle rocce carbonatiche. In: Badino V, Baldassarre G (Eds) Proceedings of the Congress "Le risorse lapidee dall' antichità ad oggi in area mediterranea" Canosa di Puglia, Italy, 25-27 settembre 2006, 399-404

Amadori ML (1985) Studi e ricerche sulle pietre del Palazzo Ducale. In: Polichetti ML (Ed), Il Palazzo di Federico da Montefeltro Restauri e Ricerche. QuattroVenti, Urbino, I:709-725

Arthur MA, Premoli Silva I (1982) Development of widespread organic carbon-rich strata in Mediterranean Tethys. In: Schlanger SO, Cita MB (eds) Nature and origin of cretaceous carbon-rich facies. Academic, London, pp 7-54

Artur MA, Fisher AG (1977) Upper Cretaceous-Paleocene magnetic stratigraphy at Gubbio, Italy: 1 - Lithostratigraphy and sedimentology. Geol Soc Am Bull 88:367-371

Baldi B (1580) Encomio della Patria a Francesco Maria II duca di Urbino. In Urbino 1706, Angelo Monticelli, 138 pp

Baldi B (1587) Descrittione del Palazzo Ducale di Urbino. A cura di A Siekiera, Collana Studi e ricerche n. 87, Edizioni dell'Orso, Alessandria 2010, $156 \mathrm{pp}$

Bams V, Dewaele S (2007) Staining of white marble. Mater Charact 58(11):1052-1062. https://doi.org/10.1016/j.matchar.2007.05 004

Bani M (1989) Monte Nerone: guida agli itinerari turistico-naturalistici. Tipo-litografica-grafica vadese, Sant'Angelo in Vado (PU), $266 \mathrm{pp}$

Barberini MG, Fei L (2017) Arredo urbano a Roma tra XVIII e XIX secolo attraverso alcuni disegni della Collezione Lanciani. Rivista dell'Istituto Nazionale d'Archeologia e Storia dell'Arte XL:72

Blanco G (1999) Dizionario dell'architettura di Pietra. Carocci Ed., $300 \mathrm{pp}$

Bonarelli G (1891) Il Territorio di Gubbio. Notizie Geologiche, Roma $1-38$

Borghi A, d'Atri A, Martire L, Castelli D, Costa E, Dino G, Favero Longo SE, Ferrando S, Gallo LM, Giardino M, Groppo C, Piervittori R, Rolfo F, Rossetti P, Vaggelli G (2014) Fragments of the Western Alpine Chain as historic ornamental stones in Turin (Italy): enhancement of urban geological heritage through geotourism. Geoheritage 6:41-55

Borghini G (1998) Marmi Antichi - Materiali della cultura artistica. De Luca Ed., 342 pp

Bourrouilh R, Bourque PA (1995b) Les calcaires à stromatactis de type Marbre Rouge Languedoc, in Archéomatériaux, marbres et autres roches, in Asmosia IV, Actes de la IVe Conférence internationale, Bordeaux - Talence, 9-13 octobre 1995, 65-76 Bordeaux

Bourrouilh R, Bourque PA (1995a) Marqueurs d'évolution de marges continentales paléozoiques: les monticules carbonatés à stromatactis. Bull Soc Géol France 166:711-724

Bradley F (2000) Marmi pregiati in architettura. Fine marble in architecture. Studio Marmo Ed. Firenze, 208 pp

Brocx M, Semeniuk V (2019) Building stones can be of geoheritage significance. Geoheritage 11:133-149

Busdraghi P, Veneri F (2003) I materiali lapidei impiegati in Urbino nell'antichità: i travertini. Atti I Congr. Naz. AIGA, 127-137

Busdraghi P, Gori U, Polidori E, Tonelli G, Veneri F (1994) Le tre cinte murarie di Urbino: stabilità e stato di conservazione. In: III Int. Symp. on the Conservation of Monuments in the Mediterranean Basin, Venice, 22-25 June 1994, 1:417-424

Busdraghi P, Veneri F (1994) Le tre cinte murarie di Urbino. Aspetti stratigrafici e morfologici del "Poggio" e caratterizzazione petrografica dei materiali da costruzione. TEMA 3:31-40 
Busdraghi P, Wezel FC (2002) Palazzo Ducale di Urbino: geologia delle colonne del "Cortile d'Onore." Rend Fis Acc Lincei $13: 5-28$

Cantalamessa G, Centamore E, Chiocchini U, Micarelli A, Potetti M, Di Lorito L (1986) Il Miocene delle Marche. Studi Geologici Camerti, special issue "La Geologia delle Marche", pp. 35-55

Capezzuoli E, Gandin A, Pedley M (2014) Decoding tufa and travertine (fresh water carbonates) in the sedimentary record: the state of the art. Sedimentology 61:1-21. https://doi.org/10.1111/sed. 12075

Capuano N, Sergenti M, Tonelli G, Veneri F (1994) Late Eocene-Oligocene carbonate turbidites in the Scaglia Cinerea of the FurloFossombrone area. Boll Soc Geol It 112:689-699

Carmignani L, Conti P, Meccheri M, Vaselli L, Mancini S, Massa G, Simoncini D (2007) Carta giacimentologica di marmi delle Alpi Apuane a scala 1:10.000 e sua informatizzazione. Centro di Geotecnologie, Dipartimento di Scienze della Terra, Università di Siena, p 105

Cecca F, Cresta S, Pallini G, Santantonio M (1990) Il Giurassico di Monte Nerone (Appennino marchigiano, Italia Centrale): Biostratigrafia, litostratigrafia ed evoluzione paleogeografica. In: Pallini G., Cecca F., Cresta S., Santantonio M. (Eds.), Atti II Convegno Internazionale "Fossili, Evoluzione, Ambiente" 1987, Ancona, Italy. Ed. Comitato Centenario R. Piccinini. 63-139

Cecca F, Macchioni F (2004) The two Early Toarcian (Early Jurassic) extinction events in ammonoids. LETHAIA 37:35-56. https:// doi.org/10.1080/00241160310008257

Centamore E, Chiocchini M, Deiana G, Micarelli A, Pieruccini U (1971) Contributo alla conoscenza del Giurassico dell'Appennino umbro-marchigiano. Studi Geol Camerti 1:7-89

Centamore E, Catenacci V, Chiocchini M, Chiocchini U, Jacobacci A, Martelli G, Micarelli A, Valletta M (1975) Note Illustrative della Carta Geologica d'Italia alla scala 1:50.000, Foglio 291, Pergola. Serv. Geol. d'It. 40 pp

Centamore E, Chiocchini M, Chiocchini U, Dramis F, Giardini G, Jacobacci A, Martelli G, Micarelli A, Potetti M (1979) Note Illustrative della Carta Geologica d'Italia alla scala 1:50.000, Foglio 301, Fabriano. Serv. Geol. d'It. 51 pp

Centamore E, Deiana G, Micarelli A, Potetti M (1986) Il Trias-Paleogene delle Marche. Studi Geologici Camerti, special issue "La Geologia delle Marche" 9-27

Coccioni R, Galeotti S (2003) The mid-Cenomanian Event: prelude to OAE 2. Palaeogeogr Palaeoclimatol Palaeoecol 190:427-440

Conti P, Cornamusini G, Carmignani L (2020) An outline of the geology of the Northern Apennines (Italy), with geological map at 1:250,000 scale. It J Geosci 139(2):149-194. https://doi.org/10. 3301/IJG.2019.25

Cooper BJ, Marker BR, Thomas IA (2013) Towards international designation of a heritage dimension stone. Key Eng Mater 548:329-335

Curto S (1965) L'obelisco di Urbino: contributo alla storia di un elemento architettonico. In: Atti del XI Congresso di Storia dell'Architettura (Pesaro, Marche 6-13 settembre 1959):549_ 568. Roma Centro di studi per la storia dell'architettura 1965

de Capoa P, D’Errico M, Di Staso A, Perrone V, Perrotta S, Tiberi V (2015) The succession of the Val Marecchia Nappe (Northern Apennines, Italy) in the light of new field and biostratigraphic data. Swiss J Geosci 108:35-54. https://doi.org/10.1007/ s00015-015-0177-0

De Wever P, Baudin F, Pereira D, Cornée A, Egoroff G, Page K (2017) The importance of geosites and heritage stones in cities - a review. Geoheritage 9:561-575

Della Porta G, Capezzuoli E, De Bernardo A (2017) Facies character and depositional architecture of hydrothermal travertine slope aprons (Pleistocene, Acquasanta Terme, Central Italy). Mar
Petrol Geol 87:171-187. https://doi.org/10.1016/j.marpetgeo. 2017.03.014

Della Torre S, Cantini L, Moioli R (2019) Stone masonry with brick stripe courses: study on a historical building technique diffused in Brianza District. In: Aguilar R, Torrealva D, Moreira S, Pando MA, Ramos LF (eds) Structural analysis of historical constructions. RILEM Bookseries, vol 18. Springer, Cham. https://doi. org/10.1007/978-3-319-99441-3_29

di Giorgio Martini Francesco (1477) Trattato di Architettura Civile e Militare. A cura di C Saluzzo \& C Promis, Torino, Tipografia Chirio e Mina, 1841, 341 pp

Donadoni AM (2001) L'obelisco di Urbino. In: Papa Albani e le arti a Urbino e a Roma 1700-1721. Urbino, Palazzo del Collegio, 29 giugno-30 settembre 2001; Roma, Chiesa del Santissimo Salvatore-Complesso Monumentale di San Michele, 25 ottobre 200113 gennaio 2002, a cura di G. Cucco, Venezia, 2001, 354-356

Donatelli U, Tramontana M (2012) Jurassic carbonate depositional systems of the Mt. Catria-Mt. Acuto area (Umbria-Marche Apennines, Italy). Ital J Geosci 131:3-18

Donatelli U, Tramontana M (2014) Platform-to-basin facies transition and tectono-sedimentary processes in the Jurassic deposits of the Furlo area (Umbria-Marche Apennines, Italy). Facies 60:541-560

Donatelli U, Tramontana M, Venturi F (2010) First record of Ammonites in the Bonarelli Level (uppermost Cenomanian) of the Umbria-Marche Succession. Ital J Geosci (Boll Soc Geol It) 129(1):69-73. https://doi.org/10.3301/IJG.2009.05

Farsani NT, Coelho COA, Costa CMM, Amrikazemi A (2014) Geoknowledge management and geoconservation via Geoparks and Geotourism. Geoheritage 6(3):185-192. https://doi.org/10.1007/ s12371-014-0099-7

Fausti A (2009) Il materiale lapideo della facciata del Duomo di Urbino (PU). Dissertation, University of Urbino Carlo Bo $87 \mathrm{pp}$

Fio Firi K, Maričić A (2020) Usage of the natural stones in the city of Zagreb (Croatia) and its geotouristical aspect. Geoheritage $12: 1-18$

Fiora L (2013) Ricami di pietra a Urbino la Città Ideale. L'informatore Del Marmista 621:32-42

Fiora L, Alciati L, Borghi A, Callegari G, Derossi A (2002) Pietre piemontesi storiche e contemporanee. L'informatore Del Marmista 489:50-59

Gambino F, Borghi A, d'Atri A, Gallo LM, Ghiraldi L, Giardino M, Martire L, Palomba M, Perotti L, Macadam J (2019) TOURinSTONES: a free mobile application for promoting geological heritage in the city of Torino (NW Italy). Geoheritage 11:3-17. https://doi.org/10.1007/s12371-017-0277-5

Giampaolo C, Lombardi G, Mariottini M (2008) Pietre e costruito nella città di Roma: dall' antichità ai giorni nostri. In: La geologia di Roma dal centro storico alla periferia, Funiciello, Praturlon, Giordano (Eds.) Mem Descr Carta Geol It 80:273-406

Guerrera F, Tramontana M, Donatelli U, Serrano F (2012) Space/ time tectono-sedimentary evolution of the Umbria-RomagnaMarche Miocene Basin (Northern Apennines, Italy): a foredeep model. Swiss J Geosci 105:325-341. https://doi.org/10.1007/ s00015-012-0118-0

Guerrera F, Martín-Martín M, Raffaelli G, Tramontana M (2015) The Early Miocene "Bisciaro volcaniclastic event" (Northern Apennines, Italy): a key study for the geodynamic evolution of the central-western Mediterranean. Int J Earth Sci (Geol Rundsch) 104:1083-1106. https://doi.org/10.1007/s00531-014-1131-5

Irfan TY, Dearman WR (1978) Engineering classification and index properties of a weathered granite. Int Ass Eng Geol Bull 17:79-90

Iversen E (1968) Obelisks in exile: I. Gad Publ Copenhagen, The obelisks of Rome. G.E.C, p 206 
Lanci L, Muttoni G, Erba E (2010) Astronomical tuning of the Cenomanian Scaglia Bianca Formation at Furlo, Italy. Earth Planet Sci Lett 292:231-237

Lezzerini M, Pagnotta S, Legnaioli S, Palleschi V (2019) Walking in the streets of Pisa to discover the stones used in the Middle Ages. Geoheritage 11:1631-1641. https://doi.org/10.1007/ s12371-019-00372-3

Lundblad SP (2019) Model for development of small carbonate platforms in the Umbria-Marche Apennines. In: Christian Koeberl, David M. Bice (Eds) 250 million years of Earth history in central Italy: celebrating 25 years of the Geological Observatory of Coldigioco. Geol Soc Am Special Paper 542, 4 nov 2019, 69-85

Luni M, Ermeti AL (2001) Le mura di Urbino tra tardo antico e Medioevo. In: Atti del I Congresso Nazionale di Archeologia Medievale, Pisa, 29-31 maggio 1997, a cura di S. Gelichi. All'Insegna del Giglio Ed., Firenze. 41-50

Luni M (1985) Urvinum Mataurense (Urbino). Dall'insediamento romano alla città medioevale. In: "Il Palazzo di Federico da Montefeltro: restauri e ricerche". A cura di M.L. Polichetti, Ed. Quattro Venti, Urbino, 11-49

Luni M (1993) Urvinum Mataurense e approvvigionamento idrico. In AA.VV., Monumenti e culture nell'Appennino in età romana, Roma, 33-64

Magi G (2012) Caratterizzazione petrografica e fisico-meccanica dei litotipi della Formazione del Calcare Massicio nella Provincia di Pesaro e Urbino. Dissertation, University of Urbino Carlo Bo 76 pp

Manzi V, Lugli S, Ricci Lucchi F, Roveri M (2005) Deep-water clastic evaporites deposition in the Messinian Adriatic foredeep (Northern Apennines, Italy): did the Mediterranean ever dry out? Sedimentology 52:875-902

Manzi V, Argnani A, Corcagnani A, Lugli S, Roveri M (2020) The Messinian salinity crisis in the Adriatic foredeep: evolution of the largest evaporitic marginal basin in the Mediterranean. Marine Petr Geol 115:1-19

Marino M, Santantonio M (2010) Understanding the geological record of carbonate platform drowning across rifted Tethyan margins: examples from the Lower Jurassic of the Apennines and Sicily (Italy). Sed Geol 225:116-137

Mazzini F (1982) I mattoni e le pietre di Urbino. Argalia Ed., Urbino, $609 \mathrm{pp}$

Micheli ME (1983) Su alcuni marmi romani di Urbino. Studi Urbinati $56: 45-59$

Del Monte M (2005) Le pietre di Bologna. Litologia di una città. Carta fronte/retro piegata in scala 1:3.500, Pignone coordinator, SELCA Firenze

Morettini E, Santantonio M, Bartolini A, Cecca F, Baumgartner PO, Hunziker JC (2002) Carbon isotope stratigraphy and carbonate production during the Early-Middle Jurassic: examples from the Umbria-Marche-Sabina Apennines (central Italy). Palaeog Palaeoclimat Palaeoecol 184:251-273

Negroni F (1993) Il duomo di Urbino. Accademia Raffaello Urbino, 201 $\mathrm{pp}$

Parisi G (1989) Stratigrafia del Cretacico-Paleogene. Mem Descr Carta Geol D'it 39:23-29

Pecchioni E, Cantisani E, Fratini F (2012) The city of Florence: an openair lithology museum. In: The Museum of Natural History of Florence v. IV, by G Pratesi, Firenze University Press (Ed), 245-268

Pedley HM (1990) Classification and environmental models of cool freshwater tufas. Sedim Geol 68:143-154

Penasa L, Franceschi M, Gattolin G, Preto N, Deseilligny M.P, Montanari A (2019) Cyclostratigraphic investigations in the Calcare Massiccio (Early Jurassic, Umbria-Marche Basin) through photogrammetry. In: Christian Koeberl, David M. Bice (Eds) 250 million years of Earth history in central Italy: celebrating 25 years of the Geological Observatory of Coldigioco. Geol Soc Am, Special Paper 542, 4 nov 2019, 87-103
Pereira D, Marker B (2016) The value of original natural stone in the context of architectural heritage. Geosciences 6((1)(13)):9. https:// doi.org/10.3390/geosciences6010013

Petti FM, Falorni P, Marino M (2007) Carta Geologica d'Italia alla scala 1:50.000 - Catalogo delle formazioni (Fascicolo VI). APAT, Dipartimento Difesa del Suolo - CNR - Commissione Italiana di Stratigrafia - Servizio Geologico d'Italia, Roma, $318 \mathrm{pp}$

Pica A, Reynard E, Grangier L, Kaiser C, Ghiraldi L, Perotti L, Del Monte M (2018) GeoGuides, Urban Geotourism Offer Powdered by Mobile Application technology. Geoheritage 10:311-326. https://doi.org/10.1007/s12371-017-0237-0

Pullen HW (2016) Manuale dei marmi romani antichi. By Crocenzi F, Gangemi (Ed), $252 \mathrm{pp}$

Punturo R, Russi LG, Giudice AL, Mazzoleni P, Pezzino A (2006) Building stone employed in the historical monuments of Eastern Sicily (Italy). An example: the ancient city centre of Catania. Environ Geol 50:156-169. https://doi.org/10.1007/s00254-006-0195-3

Rodolico F (1953) Le pietre delle città d'Italia. Le Monnier, Firenze 475 $\mathrm{pp}$

Romano M, Fabbi S, Citton P, Cipriani A (2019) The Jurassic Gorgo a Cerbara palaeoescarpment (Monte Nerone, Umbria-Marche Apennine): modelling three-dimensional sedimentary geometries. J Med Earth Sci 11:47-59

Romeo RW, Mari M, Pappafico GF, Paletta C, Tonelli G, Veneri F, Gori U (2013) Scenari di pericolosità e rischio da frana con particolare riguardo all'innesco da terremoti. Biemmegraf, Piediripa di Macerata, $112 \mathrm{pp}$

Rotondi P (1950) Il Palazzo Ducale di Urbino. Urbino, 509 pp

Santantonio M (1994) Pelagic carbonate platforms in the geologic record: their classification, and sedimentary and paleotectonic evolution. AAPG Bull 78:122-141

Santi P, Veneri F, Tonelli G, Renzulli A, Antonelli F, Tramontana M (2019) The ancient quarrying areas of the sandstones used in the UNESCO historical centre of Urbino (Marche, Italy) as inferred from geological, petro-chemical and physical-mechanical investigations. Ital J Geosci 138(3):456-470

Savelli D, Wezel FC (1978) Schema geologico del Messiniano del Pesarese. Boll Soc Geol It 97:165-188

Selbekk RS, Roaldset E, Berg H, (2012) Staining of an indoor Carrara marble floor at the Opera House, Oslo, Norway. In: Maarten ATM Broekmans (Ed) Proceeding of the 10th International Congress for Applied Mineralogy (ICAM), Springer Verlag, 641-647. https:// doi.org/10.1007/978-3-642-27682-8_77

Selli R (1954) Il Bacino del Metauro. Giorn Geol 24(2):1-294

Siegesmund S, Török Á (2011) Building Stones. In: Siegesmund S, Snethlage R (Eds) Stone in architecture. Springer, Berlin, Heidelberg, 11-95. https://doi.org/10.1007/978-3-642-14475-2_2

Silvestri L (1977) Collezione di memorie storiche tratte dai protocolli delle antiche riformanze della città di Terni dal 1378 al 1816. A cura di E Ciocca, Thyrus Ed, Terni, 812 pp

Sisti M (2019) Il monumento a Raffaello Sanzio. Vivarte, e-book con privilegio, Urbino, www.urbinovivarte.com

Taelman D, Delpino C, Antonelli A (2019) Marble decoration of the Roman theatre of Urvinum Mataurense (Urbino, Marche region, Italy): an archaeological and archaeometric multi-method provenance study. J Cult Herit 39:238-250. https://doi.org/10.1016/j. culher.2019.03.009

Tonelli G, Veneri F, Mattioli M, Paletta C (2019) The role of a bentonitic layer on slope stability in bedded limestone: the case study of the December 2004 Ca' Madonna Quarry rock slide (Umbria-Marche Apennines, Central Italy). Ital J Geosci 138:56-65. https://doi.org/ 10.3301/IJG.2018.26

Torre LF, Dino GA, Torre A, Dino M (2020) Una passeggiata in un "borgo di pietra" nelle Madonie - Geotour urbano a Petralia Sottana (PA). Pangea 3:13-25 
Tosi U (1753) Miscellanea di notizie riguardanti la storia di Urbino e dei suoi uomini illustri University of Urbino Carlo Bo, Fondo Antico del Comune, Urbino, 93, 428 pp

Tramontana M, Raffaelli G, Savelli D, Mattioli M, Ferri L (2005) Sedimentary petrography of upper Messinian sandstones in the coastal area of Eastern Marche (Italy). Boll Soc Geol It, Special Issue N 4:87-93

UNESCO (1998) http://whc.unesco.org/en/list/828/

Vernia L (2014) Le pietre della città di Reggio Emilia. Il Geologo E-R $52: 34-42$
Wezel FC (1979) The Scaglia Rossa Formation of central Italy: results and problems emerging from a regional study. Ateneo Parmense Acta Nat 15:243-259

Publisher's Note Springer Nature remains neutral with regard to jurisdictional claims in published maps and institutional affiliations. 